\title{
Gayrimenkul Davalarının Mesleki ve Teknik Bilgiyle Etkin Yönetimi İçin Ulusal Yargı Ağı İle Bütünleşik Bir Arazi Yönetimi Veri Modeli Geliştirilmesi
}

\author{
Yakup E. ÇORUHLU ${ }^{1}$, Tugay TOLUDAN ${ }^{2}$, Volkan BAŞER ${ }^{3 *}$, Okan YILDIZ $^{4}$, Bayram UZUN ${ }^{5}$
}

$\ddot{O} \mathbf{z}$

Mülkiyetine müdahale edildiğini iddia eden herhangi bir kişi temel insan haklarından olan mülkiyet hakkını korumak için dava açma hakkını kullanabilir. Bu davalarda mülkiyetin varlığı ve yapılan müdahalenin niteliği başta olmak üzere bazı belge, bilgi ve iddia birlikte değerlendirilir. Tüm verileri ve delileri birlikte değerlendiren yargı makamları, yazılı hukuk kurallarına süreci sonlandıracak kararı verir. Aslında, mahkemenin verdiği karar hâkimin yaptığı hukuki değerlendirme dışında birçok faktöre de bağlıdır. Bunlar; belge temini, davaya özgü mesleki özelliklere göre bilirkişi seçimi, olayı netleştirecek soruların belirlenmesi, bilirkişi raporunun içeriği ve doğruluğu ve gereken ideal olarak sıralanabilir. Genel problem durumu niteliğindeki mevcut sorunlar ve çözüm önerilerinin alınması adına, bu çalışmada anket yöntemi veri toplama aracı olarak kullanılmıştır. Çevrimiçi anketler, çoğunluğu akademisyen olan mühendislerden oluşan örneklem grubuna iletilmiştir. Ardından, e-devlet bileşeni olan Türkiye Ulusal Coğrafi Bilgi Sistemi (TAKBİS) ve Ulusal Yarg1 Ağı Projesi (UYAP) ile uyumlu bir şekilde gayrimenkul dava süreçleri Birleşik Modelleme Dili (UML) diyagramları ile semantik olarak modellenmiştir. Statik model, e-devlet içinde ve UYAP altındaki diğer tüm e-devlet sistemleri ile bütünleşmiş bir şekilde çevrimiçi olarak çalışabilir nitelikte UML şemaları ile tasarlanmıştır. Bu konuda araştırma yapacak olanlara, izah edilen metodolojiye uygun farklı dava konuları ile ilgili e-devlet ve UYAP içinde model tasarımı yapmaları önerilmektedir. Ancak, böyle bir tasarımın uygulanmasında; mesleki ve teknik bilgi sahibi kişiler, avukatlar ve yargıçların geliştirilen anketler ve yarı yapılandırılmış mülakat formları ile çözüm önerileri de alınmalıdır. Bu sayede sistemin tüm taraflarının beklenti ve önerileri elde edilebilir.

Anahtar Kelimeler: Mülkiyet hakkı, gayrimenkul davaları, nesne yönelimli, veri modeli, bilirkişilik, e-devlet

\section{Developing an Integrated Land Management Data Model with the National Judiciary Network for Effective Management of Real Estate Cases with Professional and Technical Knowledge}

\begin{abstract}
Any person who claims that his property has been interfered with can exercise his right to sue to protect his fundamental human right to property. In these cases, some documents, information and claims, especially the existence of property and the nature of the intervention made, are evaluated together. Judicial authorities, which evaluate all data, claims and evidence together, make the decision to terminate the process in written legal rules. In fact, the court's decision depends on many factors other than the legal assessment made by the judge. These are the provision of some legal documents, the selection of experts according to the professional characteristics of the case, the determination of the questions to clarify the case, the content and accuracy of the expert report and the ideal duration required. The questionnaire method was used as a data collection tool in this study in order to clarify the current problems and solution suggestions. Online questionnaire form was delivered to a sample group of engineers, most of whom were university academics. Then, real estate lawsuit processes were modelled semantically with Unified Modelling Language (UML) diagrams in accordance with the egovernment component, the Turkish National Geographic Information System (TAKBIS) and the National Judicial Network Project (UYAP). The static model has been designed with UML schemes that is able to work online in egovernment and integrated with all other e-government systems under UYAP. Those who will do research on this subject are recommended to design a model in e-government and UYAP on different case issues in accordance with the methodology explained. However, in the implementation of such a design; solution suggestions should also be taken from people with professional and technical knowledge, lawyers and judges through the developed questionnaires and maybe semi-structured interview forms. In this way, expectations and suggestions of all parties of the system can be obtained.
\end{abstract}

Keywords: Right to property, real estate based lawsuits, object oriented, data model, expertise, e-government

\footnotetext{
1,2,4,5Karadeniz Teknik Üniversitesi, Mühendislik Fakültesi, Harita Mühendisliği Bölümü, Trabzon, Türkiye, yecoruhlu@ktu.edu.tr, toludantugay@gmail.com, okan.yildiz@ktu.edu.tr, buzun@ktu.edu.tr

${ }^{3}$ Giresun Üniversitesi, Mühendislik Fakültesi, Harita Mühendisliği Bölümü, 28200 Giresun, Türkiye, volkan.baser@giresun.edu.tr

${ }^{1}$ https://orcid.org/0000-0002-8673-603X $\quad{ }^{2}$ https://orcid.org/0000-0003-0152-1177

${ }^{4} \mathrm{https}: / /$ orcid.org/0000-0002-7664-5361 $\quad{ }^{5} \mathrm{https} / / /$ orcid.org/0000-0001-6492-6820

hhttps://orcid.org/0000-0001-5353-2287
} 


\section{Giriş}

Mülkiyet hakkı Eflatun ve Aristo'dan bu yana en çok tartışılan kavramlardan biridir. Mülkiyet hakkı, eşya üzerinde en geniş yetkileri sağlayan ayni bir haktır (Özdemir, 2018; Özel, 2006). Dünya'da mülkiyet hakkına yönelik; klasik, sosyalist ve karma olmak üzere üç farklı yaklaşım bulunmaktadır (Gözler, 2019). Klasik görüşe göre birey devlet ortaya çıkmadan önce de bazı haklara sahiptir. Dolayısıyla bireylerin sahip olduğu hakların kaynağı devlet değildir (Etgü, 2009). Klasik yaklaşımın en katı şekli, devletin mülkiyet hakkına kesinlikle müdahale etmemesini öngörür (Eren, 1977). Özel mülkiyeti insanın insanı sömürmesinin en önemli sebebi olarak gören sosyalist yaklaşım ise mülkiyetin toplumlaştırılmasını savunur (Eren, 1977). Bu görüşe göre mülkiyetin toplum yerine bireyde olması birçok sosyal adaletsizliği doğurmaktadır (Şimşek, 2010). Karma görüş ise, kamu yararı ile özel mülkiyetin kısitlanabileceği ilkesine dayanmaktadır (Eren, 1977; Eren, 2012). Mülkiyet; elinde bulunduranın özelliğine göre ise, özel ve kamu mülkiyeti olmak üzere ikiye ayrılmaktadır (Bruce, 1998). Taşınmaz mülkiyetinin konusunu; arazi, arsa ve bina olarak ifade edilen eşyaları oluşturmaktadır (Dale \& McLaughlin, 1999). Mülkiyet hakkı sahibine bu eşyalar üzerinde kullanma, yararlanma ve tasarruf etme hakkını vermektedir (Şekil 1).

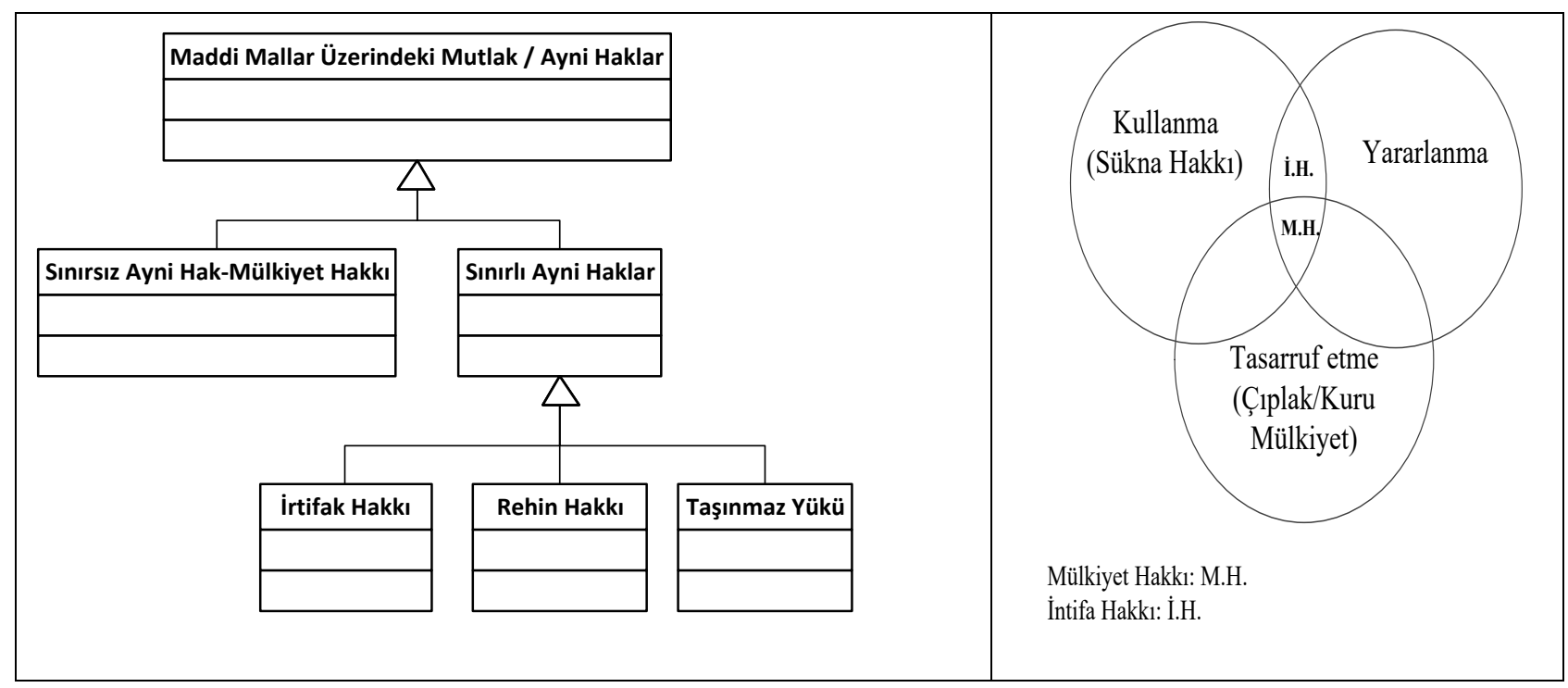

(a)

(b)

Şekil 1. Mülkiyet hakları: (a) kavramsal model, (b) Mülkiyet haklarının Venn diyagramı (Coruhlu vd., 2020).

Sınırsız bir ayni hak olarak tanımlanan mülkiyet hakkı, taşınmaz malikine bazı ödev ve yetkiler de yüklemiştir (Şekil 2). Türk Anayasası'nın 35'inci maddesi ile Türk Medeni Kanunun (TMK) 683'üncü maddesi, mülkiyet hakkını doğrudan anayasal güvence altına almıştır (Çoruhlu vd., 2016). 


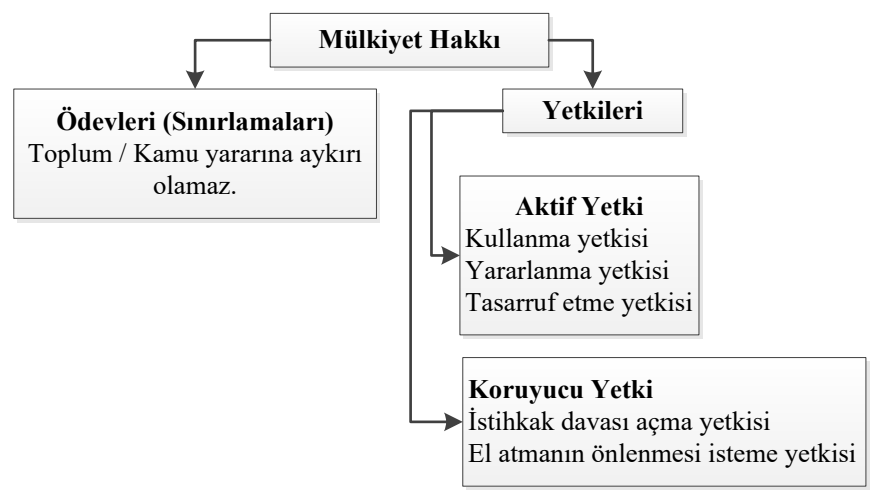

Şekil 2. Mülkiyet Hakkının Ödev ve Yetkileri

Malik, eşya üzerinde yasaların öngördüğü biçimde dilediği gibi tasarruf edebilme imkânına sahiptir (Coruhlu vd., 2020). İki ya da daha fazla taraf arasında fikir ayrılıkları veya menfaat çatışmalarından doğan uyuşmazlıkları, devlet adına çözüme kavuşturma mercii bağımsız mahkemelerdir. Mahkemelerin tabii olduğu kuralların sebep olduğu bürokrasi, zaman zaman uyuşmazlıkların çözüme kavuşturulması sürecini karmaşık hale getirebilmektedir (Türk, 2005). Hukuki uyuşmazlıkların karmaşıklığı, dava konuları özelinde uzmanlık sahibi kişilere olan ihtiyacı artırabilmektedir. Hâkimin, hukuki unsurlar etrafında çözümleyemediği, özel veya teknik bilgi gerektiren, davalar olabilmektedir. Bu tip davalarda konu hakkında uzmanlığı bulunan kişilere başvurulması, davanın sonucu açısından önemlidir (Akil, 2011).

Taraflar; mülkiyet hakkı, sınırlı bir ayni hak veya gayrimenkulü esas alan bir sözleşmeye dayanarak birbirlerine karşı çok sayıda dava açabilmektedir. Mülkiyet hakkı, mülkiyete konu eşyanın kullanımı, yararlanılması ve eşya üzerindeki tasarruf edilmesi hususunda hak sahibine yetkiler sunar. $\mathrm{Bu}$ yetkilerin ihlali durumunda, hak sahibine yasal yollara başvurabilir (Özdemir, 2018).

\subsection{Problemin tanımı ve çalışmanın amacı}

Gayrimenkul davalarında anayasal olarak güvence altına alınmış mülkiyet hakkı ve dava açma hakkı ile karşılaşılmaktadır. Bu davalarda bilirkişilerin seçimi ile bilirkişi raporunun gerekli verileri içerecek şekilde özenle hazırlanması son derece önem arz etmektedir. Bilirkişilik hizmeti davaların sonuçlandırılmasında uzman görüşüne ihtiyaç duyulması durumunda başvurulan bir yöntem (Akil, 2011; Güler \& Karaca, 2017; Meriç vd., 2016; Papakç1, 2016) olmasına rağmen, davaların türüne göre bilirkişi raporlarında hangi bilgi/belgelerin bulunması gerektiğine dair standart bir veri paylaşımına ulaşılamamaktadır. Mülkiyete yönelik bu özel ve teknik bilgi; başta sınırsız ayni hak olan mülkiyet hakkı, sınırlı ayni haklar, tapu sicilindeki kısıtlamalar ve sınırlamalar, kadastro tekniği, imar hakları vb.dir. Arazi idaresi kavramı taşınmaz yönetimi altında esasında taşınmazlara yönelik tüm grafik ve sözel verilerin ele alındığı bir yönetim sistemidir. Bilirkişi ve uzman marifeti ile arazi 
idare sisteminde olması beklenen taşınmazlara yönelik özel ve teknik bilgilere sağlıklı bir şekilde eriştikten sonra, mahkemeler daha hızlı kararlar verilebilir. Diğer bir husus ise, gayrimenkul davaları ile meslek disiplini ilişkinlerinin kurulmasıdır. Bu konu da mahkemeler, farklı heyetlerin verdiği çok farklı uzman görüşleri ile baş başa kalabilmektedir. Yargılama sırasında uzmanlık alanı ve bilirkişi seçiminden, gerekli bilgi ve belgelerin belirlenmesi sürecindeki sorunlar bir problem durumu olarak bu çalışmada ele alınmıştır.

Çalışmada öncelikli olarak, mevcut durumun analiz edilmiştir. Diğer taraftan anket yöntemi ile meslek disiplinlerinde lisans düzeyinde (Çoruhlu ve Demir, 2014) verilen derslerin dava konuları ile ilişkisi, çalışmaya konu meslek disiplinlerinin taşınmaz tabanlı davaların hangilerinde ne kadar sıklıkla görev aldığı ve ne kadar rapor hazırlandığı gibi bilgilere erişmek ilk aşamada hedeflenmiştir. Zira dersler taşınmaz davalarına ilişkin konuları da içerdiğinden dolaylı olarak dava konuları ile dersler ve mesleki disiplinlerin ilişkilendirilmesi de sağlanabilir. Ardından, arazi idare sistemi içindeki taşınmazlardan davalara konu olanlarının, davaya ilişkin grafik ve sözel verilerini ele alan, bu verileri e-devlet içindeki sorumlu kurumlar üzerinden sağlamaya imkân veren nesne tabanlı bir veri tabanı tasarımı gerçekleştirilmesi amaçlanmıştır.

\subsection{Literatür}

\subsubsection{Türk Yargı Sistemi}

Türk Anayasası'nın dokuzuncu maddesine göre yargı yetkisi Türk milleti adına bağımsız ve tarafsız mahkemelerce kullanılmaktadır (Resmi Gazete, 1982b). Türk Yargı Sistemi, anayasa yargıs1, adli yargı, idari yargı, mali yargı ve uyuşmazlık yargısı olmak üzere beş grupta toplanmaktadır (Benli, 2015; Görgülü, 2005; Küçükyağc1, 2012). Adli ve idari yargıyı temsil eden uyuşmazlık yargısının teşkilat yapısı ise tablo 1'de sunulmuştur.

Türkiye'de adli yargı, ilk derece, ikinci derece ve üst derece mahkemelerinden oluşan üç dereceli bir yargılama sistemine sahiptir (Küçükyağc1, 2012).

Adli yargı; diğer yargı kollarının görev kapsamı dışında kalan ve genellikle özel hukukun konusu olan davalarla ilgilenir (Yeşil, 2015). Adli yargı ceza yargısı ve medeni yargı olmak üzere sınıflandırılır (Benli, 2015; Küçükyağc1, 2012; Yeşil, 2015). Hukuk yargısı, sulh ve asliye hukuk mahkemeleri ile özel kanunlarla kurulan diğer uzmanlık mahkemelerinden oluşur (Küçükyağc1, 2012; Yeşi1, 2015). 
Ayrıca kadastro komisyonu tarafından gönderilen kadastro tutanaklarına ait davalar, mahalli hukuk mahkemelerinde görülmekte olan kadastro ile ilgili henüz kesinleşmemiş davalar bu mahkemenin yetki alanındadır.

Diğer ilk derece mahkemeleri ise idari mahkemelerdir. Bu mahkemeler nezdinde açılabilen davalar şunlardır. İdari işlemler hakkında yetki, şekil, sebep, konu ve maksat yönlerinden biri ile hukuka aykırı olduklarından dolayı iptalleri için menfaatleri ihlâl edilenler tarafindan açılan davalardır. Bu davalar; iptal davaları ve İdarî eylem ve işlemlerden dolayı kişisel hakları doğrudan muhtel olanlar tarafından açılan tam yargı davalarıdır. İdari yargı yetkisi, idari eylem ve işlemlerin hukuka uygunluğunun denetimi ile sınırlıdır. İdari mahkemeler; yerindelik denetimi yapamazlar, yürütme görevinin kanunlarda gösterilen şekil ve esaslara uygun olarak yerine getirilmesini kısıtlayacak, idari eylem ve işlem niteliğinde veya idarenin takdir yetkisini kaldıracak biçimde yargı kararı veremezler (Gazete, 20.01.1982).

Yargılamanın ikinci basamağını adli yargılamada bölge adliye mahkemeleri, idari yargılamada ise bölge idare mahkemeleri oluşturmaktadır. Bu mahkemelerde ilk derece mahkemelerinin almış olduğu kararların denetimi yapılmaktadır (Küçükyağcı, 2012).

Yargılamanın temyiz sürecinde hukuk mahkemeleri için Yargıtay ve idari mahkemeler için Danıştay rol oynamaktadır (Yeşil, 2015). Yargıtay’ın adli yargı mercileri arasında, Danıştay’ın idari yargı mercileri arasında nihai karar verici konumunda olduğu görülmektedir (Görgülü, 2005).

Dava sayısı ve çeşidi olarak taşınmazlarla ilgili davalar daha çok hukuk mahkemelerine açılmaktadır. 2010-2017 yılları arasında ilk derece adli mahkemeler ile Yargıtay'da davaların ortalama görülme süreleri (Tablo 2) analiz edildiğinde sekiz yıllık süreçte davaların Asliye Hukuk Mahkemelerinde ortalama bir yıla, Kadastro Mahkemelerinde ise ortalama iki yıla yakın sürelerde tamamlanabildiği görülmektedir. Ayrıca 2010 yılından itibaren davaların ortalama görülme sürelerinde artış dikkati çekmektedir

(http://www.Adlisicil.Adalet.Gov.Tr/Istatistik_2017/Istatistik2017.Pdf." 2017).

Tablo 2. 2010-2017 yılları arasında bazı adli mahkemelerde davaların ortalama görülme süreleri.

\begin{tabular}{|c|c|c|c|c|}
\hline Millar & $\begin{array}{c}\text { Asliye } \\
\text { Hukuk }\end{array}$ & $\begin{array}{c}\text { Sulh } \\
\text { Hukuk }\end{array}$ & Kadastro & Yargitay \\
\hline 2010 & 299 & 109 & 578 & 159 \\
\hline 2011 & 315 & 106 & 828 & 160 \\
\hline 2012 & 330 & 117 & 755 & 131 \\
\hline 2013 & 303 & 99 & 472 & 117 \\
\hline 2014 & 278 & 91 & 586 & 122 \\
\hline 2015 & 282 & 90 & 545 & 165 \\
\hline 2016 & 350 & 93 & 678 & 286 \\
\hline 2017 & 419 & 105 & 992 & 451 \\
\hline ORTALAMA & 322 & 101 & 679 & 199 \\
\hline
\end{tabular}


Adli mahkemelerde toplam iş yükü, bir önceki seneden devreden, y1l içerisinde gelen toplam dava sayıları ve bu davaların yıl içerisinde karara bağlanma yüzdeleri, Tablo 3 ile sunulmuştur (http://www.Adlisicil.Adalet.Gov.Tr/Istatistik_2017/Istatistik2017.Pdf." 2017). Asliye Hukuk ve Kadastro Mahkemeleri özelinde bakıldı̆̆ında davaların her yıl neredeyse yarısı veya yarısından fazlasının karara bağlanamadığg görülmektedir. Kadastro Mahkemelerinde 2016 ve 2017 yıllarında her üç davadan yalnızca bir tanesinin karara bağlanabildiği dikkat çekmektedir. Yargıtay’da 2016 yılına kadar davaların yüksek oranda karara bağlanmasına karşın 2016 ve 2017 yıllarında oranın \%50 seviyelerine indiği gözlenmektedir. Sulh Hukuk Mahkemelerinde ise ortalama dört davadan üçünün karara bağlanabildiği bir durum söz konusudur.

Tablo 3. 2010-2017 yılları arasında bazı adli mahkemelerde görülen ve karara bağlanan dava sayıları (http://www.Adlisicil.Adalet.Gov.Tr/Istatistik_2017/Istatistik2017.Pdf." 2017).

\begin{tabular}{|c|c|c|c|c|c|c|c|c|c|}
\hline & & 2010 & 2011 & 2012 & 2013 & 2014 & 2015 & 2016 & 2017 \\
\hline \multirow{3}{*}{$\begin{array}{l}\text { Asliye } \\
\text { Hukuk }\end{array}$} & Toplam & 770923 & 830513 & 868927 & 943301 & 1042396 & 1098001 & 1068884 & 1073466 \\
\hline & Karara Bağlanan & 398312 & 427170 & 441282 & 509044 & 573238 & 602676 & 510661 & 477285 \\
\hline & Yüzde (\%) & 52 & 50 & 51 & 54 & 55 & 55 & 48 & 44 \\
\hline \multirow{3}{*}{$\begin{array}{c}\text { Sulh } \\
\text { Hukuk }\end{array}$} & Toplam & 937345 & 935623 & 730342 & 687274 & 701939 & 709079 & 762531 & 806469 \\
\hline & Karara Bağlanan & 715737 & 731321 & 576120 & 544351 & 562502 & 565281 & 592970 & 612363 \\
\hline & Yüzde (\%) & 76 & 78 & 79 & 79 & 80 & 80 & 78 & 76 \\
\hline \multirow{3}{*}{ Kadastro } & Toplam & 115226 & 89959 & 71208 & 68290 & 49118 & 36036 & 28734 & 25290 \\
\hline & Karara Bağlanan & 44107 & 35649 & 28993 & 33043 & 23460 & 18196 & 9047 & 7859 \\
\hline & Yüzde (\%) & 38 & 40 & 41 & 48 & 48 & 50 & 32 & 31 \\
\hline \multirow{3}{*}{ Yargitay } & Toplam & 524829 & 582565 & 659810 & 672061 & 725664 & 751543 & 785609 & 674471 \\
\hline & Karara Bağlanan & 352997 & 395586 & 494230 & 507521 & 522884 & 482621 & 358522 & 351562 \\
\hline & Yüzde (\%) & 67 & 68 & 75 & 76 & 72 & 64 & 46 & 52 \\
\hline
\end{tabular}

\subsubsection{Bilirkişilik Müessesesi}

Yargısal faaliyetin gerçekleştirilmesi sırasında, çözümü özel veya teknik bilgiyi gerektiren hukuki uyuşmazlıklarda hâkim bilirkişiye başvurabilir (Kök, 2017). Günümüzde bilirkişiliğin etkinliği giderek artmaktadır (Meriç vd., 2016). Bilirkişi raporları, teknik bilgiye dayalı belgelerdir. Yargının kararını etkileyecek yorum ve değerlendirmelerden uzaktır. Raporlar, hâkimin kararını bağlayıcı nitelikte değildir (Güler \& Karaca, 2017).

Bilirkişi incelemesi bazı durumlarda hâkimlerin takdirine bırakılırken, kimi davalarda yasa hükmü ile zorunlu kılınmıştır. Örneğin; Kamulaştırma Kanunu'nun (Resmi Gazete, 8.11.1983) 10. maddesinde taşınmaz malın değerinin tespiti konusunda, Türk Medeni Kanununun (Resmi Gazete, 8.12.2001) 165. maddesinde akıl hastalığı nedeniyle açılan boşanma davasında davalının akıl hastası olup olmadığı konusunda, yine aynı kanunun 409. maddesinde akıl hastalığı nedeniyle hacir kararı 
verilmesinde veya böyle bir kararın kaldırılmasında, Türk Borçlar Kanununun (TBK) (Resmi Gazete, 4.2.2011) 199. maddesinde hayvan alım satımında hayvanın ayıplı olup olmadığı konusunda, Orman Kanununun (Resmi Gazete, 8.9.1956) dokuzuncu maddesinde orman kadastrosu konusunda bilirkişi incelemesi yapılması gerektiği düzenlenmiştir (Yıldırım vd., 2016).

\subsubsection{Türkiye’nin E-Devlet Politikası Çerçevesinde Ulusal Yargı Ağı Projesi (UYAP)}

Kamu yönetiminin hizmetlerin sürdürülebilirliği açısından değişen sosyo-ekonomik koşullara uyarlanması gerekmektedir (Avaner \& Fedai, 2019). E-devlet, Türkiye'de kamusal hizmetlerin bilişim teknolojileri üzerinden yürütülmesini sağlayan bir modeli ifade etmektedir (Odabaş, 2008). Türkiye gibi gelişmekte olan ekonomiler açısından kamu hizmetlerinin e-devlet yoluyla sunumu mali tasarruf açısından çok önemlidir. Ayrıca ülke veya dünya genelinde oluşabilecek küresel salgınlarda oluşacak sokağa çıkma yasaklarında iş ve işıleyişin devam edebilmesi için e-devlet uygulamaları büyük önem arz etmektedir. Bu bağlamda e-devlet, devlet ile vatandaşların karşılıklı veri alış verişine imkân tanıma ve iş süreçlerini elektronik ortama taşıma misyonunu üstlenmektedir (Güreler, 2011). $\mathrm{Bu}$ sayede vatandaş ile kurumlar arası bilgi ve belge alış verişleri geleneksel metottan modern elektronik boyuta taşınır (Taş vd., 2017). Her ne kadar e-devlet adı altında yapılan girişimler kamu yönetiminde dijitalleşmenin başlangıcı sayılsa da ortaya çıkan sorunlar e-devlet dönüşümünün tamamlanması adına önemli bir reform girişimi olarak ifade edilebilir (Avaner \& Fedai, 2019).

En önemli e-devlet uygulamalarından biri de Ulusal Yargı Ağı Projesi (UYAP)'dır. UYAP, adli süreçlerde zaman, maliyet açısından tasarruf sağlamak, işlem süreçlerini hızlandırmak, ulaşılabilir verilerle denetlenebilir bir yargı yapısını inşa etmek amacıyla geliştirilen bir bilişim sistemidir (Güzel \& Deligöz, 2014). UYAP, e-adalet sisteminin bir parçası olarak yargı alanındaki e-devlet uygulamalarının işlevini üstlendi (Sezer \& Cengiz, 2019). UYAP, adli hizmetlerde etkinlik, verimlilik, hız ve tasarruf sağlamak suretiyle Adalet Bakanlığı'nın son dönemdeki en önemli projesi olarak yerini almaktadır (Türkan \& Erdinçertürk, 2017). Gerek Avrupa İnsan Hakları Sözleşmesi (AİHS) (Avrupa İnsan Hakları Sözleşmesi, 1950) 6. maddesi ve gerekse Türkiye Cumhuriyeti Anayasası (Resmi Gazete, 1982b) 141. Maddesi, davaların makul sürede tamamlanmasının önemine işaret etmektedir. UYAP, bilişim çağına uygun hızlı, etkin, verimli yapısı ile ulusal ve küresel mevzuatlara uygun bir yargılama sürecinin önünü açmaktadır (Batır, 2013). 


\subsubsection{Gayrimenkul Davaları}

Gayrimenkule ilişkin davalar eşya hukukunu ilgilendiren dava türleridir. $\mathrm{Bu}$ dava türlerinin temel bileşenini arsa, arazi veya mesken vb. bağımsız bölümlere ilişkin haklar oluşturur. Gayrimenkule ilişkin davalar arasında kamulaştırma davaları, tapu iptal ve tescil davaları, ortaklığın giderilmesi davaları başta olmak üzere oldukça fazla dava türü bulunur. Bu davaların yürütülmesinde, temel iş akışı (Şekil 3) şu şekildedir.

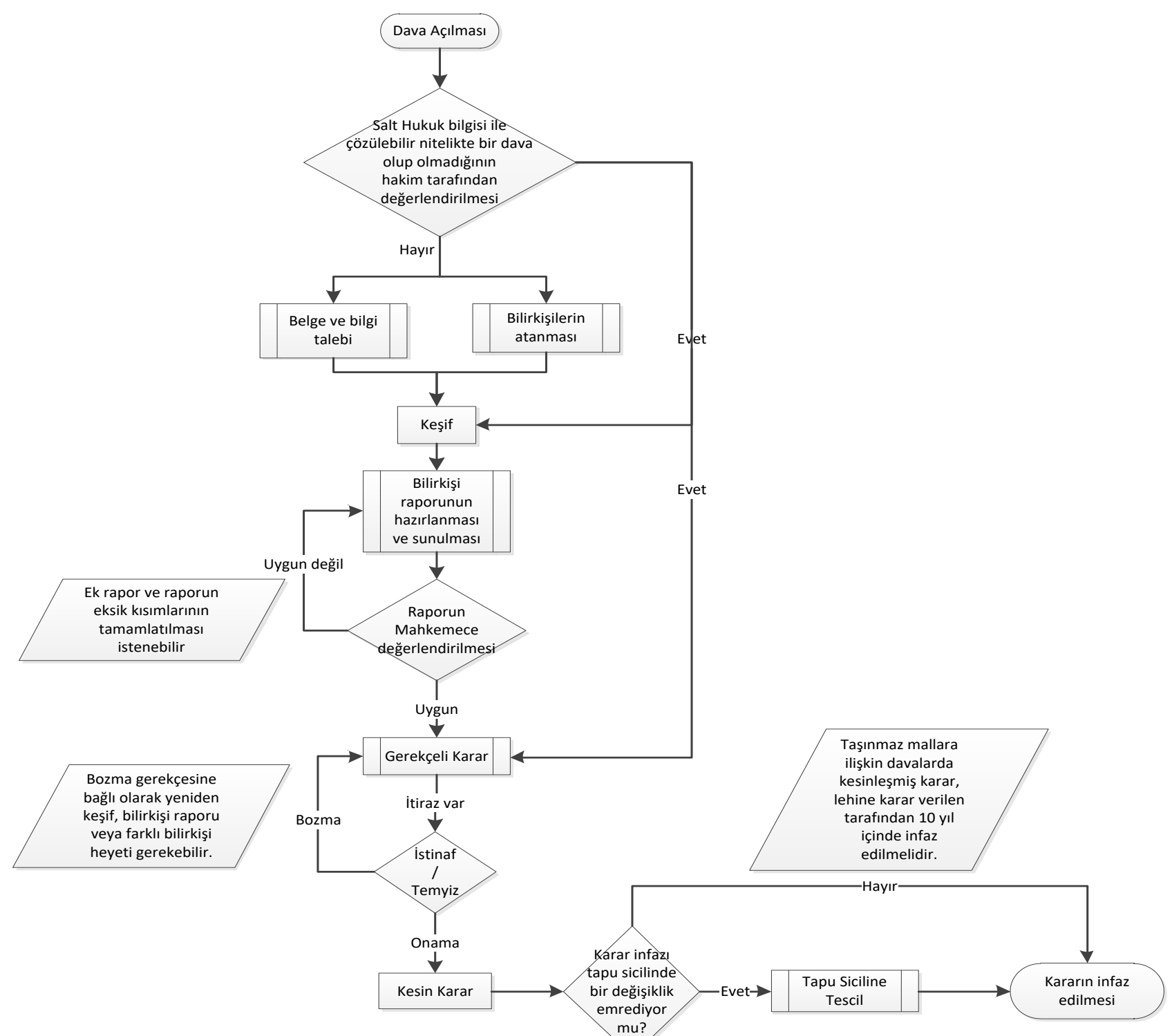

Şekil 3. UML iş akış diyagramı ile gayrimenkul dava sürecinin görselleştirilmesi

Çalışma özelinde ele alınan gayrimenkule ilişkin bazı davalar aşağıda sunulmuştur: 


\subsubsection{El atmanın önlenmesi davaları}

Taşınmaz malikinin, taşınmaz malına karşı haksız kullanım söz konusu olması durumunda müdahaleyi önlemek üzere açtığı davadır. Bu davalar, kamulaştırmasız el atma davaları, ölünceye kadar bakma sözleşmesinden kaynaklı davalar, satın almaya dayalı davalar, satış vaadi sözleşmesine dayalı davalar, tapu tahsisi belgesine dayalı davalar, taşınmazın orman niteliğinin çekişmeli olmasına ilişkin davalar vb.dir (https://vatandas.uyap.gov.tr/main/vatandas/index.jsp?v=1288, 2020). Bunlardan biri olan kamulaştırmasız el atma davasıdır (Şahiniz, 2006). Bu davalar; kanuna dayanmaksızın, usulüne uygun bir kamulaştırma kararı almadan veya taşınmazın ederine uygun bir bedel ödemeden özel mülkiyetteki bir mala, hukuki olmayan bir şekilde el konulması olarak tanımlanır (Göktepe, 2010).

\subsubsection{Kamulaştırma davaları}

Kamulaştırma Kanununa göre yapılacak bir kamulaştırmada, idare ile taşınmaz maliki anlaşamaması durumunda iki dava türü karşımıza çıkar. Kamulaştırma işlemleri için idari yargıda da açılabileceği gibi, davanın konusuna göre, adli yargıda da dava açılabilmektedir İdare Hukuku kapsamında kamulaştırma işleminin denetlenmesi ve işlemin iptali için idari yarıda iptal davası malik tarafından açılabilir. Bu davalarda, malik taşınmazın bulunduğu mahaldeki İdare Mahkemelere davayı açar. Bu dava açılmadığı takdirde kamulaştırma işlemi devam eder. Bu süreçte ise malik, taşınmazı için ödenen bedeli kamu etmezse, idare tarafından taşınmaz maliki aleyhine yetkili asliye hukuk mahkemesinde dava açılır. Bu dava kamulaştırma bedelinin tespiti ve tescil davası olarak adlandırılır (Ercan, 2000). Kamulaştırma esnasında arazi üzerinde bulunan muhdesatların unutulması, arazi üzerindeki unsurların kamulaştırma bedeli kapsamına alınmaması, taşınmazın tapuda yer alan gerçek yüzölçümünün eksik gösterilmesi gibi sebeplerden maddi ve fiziki hatalar olabilmektedir. Bu hataları ortadan kaldırmak için 'maddi hata düzeltim davaları' açılabilmektedir (Pehlivan, 2008).

\subsubsection{Kat mülkiyeti davaları}

Kat mülkiyetine ilişkin açılabilecek davalar ve sürecin nasıl işleyeceği Kat Mülkiyeti Kanunu (KMK) (Resmi Gazete, 2.7.1965) içerisinde kendine yer bulmuştur. Bu bağlamda yapılı bir taşınmazdaki bazı ortaklığın giderilmesi davalarında, ana gayrimenkulün kat mülkiyetine dönüştürülmesi ve maliklere payları ile orantılı bağımsız bölümlerin verilmesi suretiyle gerçekleştirilebileceği vurgulanmaktadır. Bunun dışında hatalı arsa payının düzeltilmesi davası da 
açabilmektedirler. Kat irtifakı paydaşlarının arsaları üzerine yapılacak yapının sözleşmede belirtilen süre içerisinde tamamlanmasını istemini dava etme hakları bulunmaktadır. Kat mülkiyetine ilişkin uyuşmazlık konusu diğer hususlar şu şekilde özetlenebilir: reklam panoları ile ilgili kat malikleri arasındaki uyuşmazlıklar, apartmanda yasaya aykırı işyeri açılması, ana taşınmaz ortak giderlerine ilişkin uyuşmazlıklar vb.

\subsubsection{Tapu İptali ve Tescil Davaları}

Tapu sicilinin, yasalara aykırı, usulsüz veya yolsuz düzenlendiği iddiasıyla, tapuda tescilli malik aleyhine açılan davadır. Bu davalar; muris muvazaası, vekâletin kötüye kullanılması, temyiz kudreti ve ehliyetsizlik gibi pek çok sebepten kaynaklanabilir. TMK 1025. Maddesinin birinci fikrası, ayni hakkı yolsuz bir biçimde ortadan kaldırılmış şahsın tapu sicilinin düzeltilmesi maksadıyla yolsuz tescilin düzeltilmesi (tapu sicilinin tashihi) davası açabileceğini öngörmektedir (Özmen \& Aydın, 2014).

Kadastro sonucu taşınmaz mal olarak tescil edilen bazı taşınmazların, daha sonra yapılan orman kadastrosu çalışmaları uyarınca tapu kayıtlarının iptal edilmesi durumu da bu davalara sebep olabilir (Gençay, 2016).

Tapu iptal ve tescil davaları kapsamında değerlendirilen eski kaydın ihyası davalarını açabilmek için öncelikle idarece yapılan parselasyon işleminin iptali yönünde başvurunun olması gerekmektedir. Parselasyon süreci, idareler eliyle yürütülen süreçleri ifade etiği için iptal davasının idari yargıda açılması gerekmektedir. Genel kabulün İdari yargıda açılan parselasyon işleminin iptali istenmeden doğrudan adli yargıda eski kaydın ihyası davası açılamayacağı yönünde olmasına karşın Yargıtay tarafından alınan bazı kararlar, doğrudan adli mahkemede eski kaydın ihyası davalarının açılabileceğine de işaret etmektedir. Davacı, itirazını parselasyon işlemine değil de doğrudan mülkiyetine yönelik bir ihlale yöneltebiliyorsa parselasyon işleminin iptal davası aranmadan doğrudan tapu iptal ve tescil davası açabilmektedir (Şimşek, 2014).

\section{Yöntem}

$\mathrm{Bu}$ bölüm üç başlık altında ele alınmıştır. Bunlar; anket formunun geliştirilmesi ve uygulanması, davaların karara bağlanmasına gerekli olan belge ve bilgilerin tespit edilmesi ve veri modeli tasarımıdır. Gayrimenkul davaları içinden örnek olarak seçilen pilot davalarda olması gerektiği düşünülen bilgi ve belgelerin tespit edilmesi ilk aşamada ele alınmıştır. Ardından anket sorularının hazırlanması ve örneklem grubu olarak belirlenen özel ve teknik bilgi sahiplerinin 
görüşlerinin alınması planlanmıştır. Son aşamada ise elde edilen bu veriler ışığında e-Türkiye kapısı altında ve diğer bilgi sistemleri ile entegre bir veri modeli tasarımı yapılması planlanmıştır.

Çalışma kapsamında; el atmanın önlenmesi, kadastro, kamulaştırma, tapu iptali ve tescil, tapu kaydında düzeltim ile kat mülkiyeti davalarına, e-devlet kapısı aracılığı ile UYAP Vatandaş Portalı (UYAP, 2020) üzerinden erişim sağlanmıştır. Asliye hukuk, sulh hukuk ve kadastro mahkemeleri için ayrı ayrı sorgulamalar yapılarak çalışmaya konu dava türlerinin kapsamına giren dava konuları elde edilmiştir. Konularına göre gayrimenkul davalarının ilk derece adli mahkemelerden hangisinin görev ve yetki sahasına dâhil olduğunu saptamak için, sulh ve asliye hukuk mahkemelerinin görev sınırlarını belirleyen ‘Adlî Yargı İlk Derece Mahkemeleri ile Bölge Adliye Mahkemelerinin, Kuruluş, Görev ve Yetkileri Hakkında Kanun'dan (Resmi Gazete, 7.10.2004) faydalanılmıştır. Ayrıca Kadastro Mahkemeleri için 3402 sayılı Kadastro Kanunu’ndan (Resmi Gazete, 9.7.1987) yararlanılmıştır. Yargıtay Hukuk Dairelerinin görevlerini tanımlayan 'Yargıtay Büyük Genel Kurul Kararı' (Resmi Gazete, 26.1.2013) incelenerek dava konularına göre hangi dairenin yetkili kılındığı göz önüne alınmıştır.

Gayrimenkul davaları, birçok meslek kolunun dâhil olduğu geniş kapsamlı bir süreci ifade etmektedir. Ele alınan davalarla ilgili olabilecek meslek disiplinleri ile ilgili bilgilerin bizzat o meslek grubuna mensup bireylerden almak, muhakkak daha sağlıklı bir analizin önünü açacaktadır. Böylece, her bir meslek disiplininin gayrimenkul davalarıyla olan ilişkisini test etmek maksadıyla çevrimiçi olarak yanıtlanmaya uygun “Dava-Taşınmaz-Meslek Disiplinlerinin Araştırılması” başlığı altında bir anket formu geliştirilmiştir.

Araştırmada, özel durum yöntemi kullanılmıştır. Özel durum yöntemi, bir olayı derinlemesine incelemeye imkân sağlayan bir yöntemdir (Denscombe, 2014; Wellington, 2015). Bu yöntem bir durumun özelliği ve kompleksliği üzerine odaklanarak (Cohen vd., 2013; Çepni, 2010) örneklem grubu ile olay ya da vakanın derinlemesine incelenmesine imkân sağlar (Çepni, 2010). Nitekim bu yöntem anket, mülakat ve gözlem gibi nicel ve nitel farklı veri toplama araçlarının tek tek veya bir arada kullanılmasına imkân sağlamaktadır (Cohen vd., 2013; Çepni, 2010). Bu çalışmada ele alınan davalarla ilgili olabilecek kişilerin sahip oldukları görüş ve düşüncelerinin ayrıntılı incelenmesi amaçlandığından özel durum yönteminin kullanılmasına karar verilmiştir.

Geliştirilen anket formuyla örneklem grubunun; cinsiyet, meslek disiplinleri, unvanları, çalıştıkları kurum, mesleki deneyimleri, eğitim durumları, herhangi bir uzmanlık belgesine sahip olup olmadıkları gibi demografik bilgileri edinilmiştir. Ardından örneklem grubuna, daha önce taşınmaz tabanlı davalarda bilirkişi olarak görev alıp almadıkları, bu davalar için bilirkişi raporu düzenleyip düzenlemedikleri ve taşınmaz tabanlı davalar için rapor düzenleyen katılımcıların rapor düzenleme sıklığına dair çoktan seçmeli sorular yöneltilmiştir. Anket formunun son kısmında arsa-arazi-bina nitelikli taşınmazların konu edildiği davaların yer aldığı tablo ile örneklem grubunun hangi dava 
türünün neresinde görev almasının uygunluğu sorulmuştur. Geliştirilen çevrimiçi anket formu farklı üniversitelerin farklı bölümlerine ve meslek odası mensuplarına uygulanmıştır. 260 öğretim elemanına; TMMOB'a bağlı oda ve Türkiye Değerleme Uzmanları Birliği’ni (TDUB) içine alan 24 kuruluşa elektronik posta yoluyla anket online olarak gönderilmiştir.

Çalışmanın son bölümünde LADM'ye uygun şekilde geliştirilen TUCBS veri temaları dikkate alınarak bir veri modeli yaklaşımı sunulmuştur. Arazi idaresi sistemlerinde mevcut olan ve olmayan bilgiler ayrı ayrı ele alınmıştır. UML diyagramları ile modellenen ve UYAP entegrasyonu ile uygulama imkânı bulabilecek bir nesne tabanlı veri modeli tasarımı gerçekleştirilmiştir.

\section{Sonuçlar ve Tartışma}

\subsection{Gayrimenkul davalarında gerekli bilgi ve belge gereksinimi}

Çalışmada; el atmanın önlenmesi, kadastro, kamulaştırma, tapu iptali ve tescil, tapu kaydında düzeltim ile kat mülkiyeti davaları gibi on bir farklı dava türü incelenmiştir. Bu amaçla her bir dava türüne ait kesinleşmiş mahkeme kararlarına ait üç-beş dava dosyası ele alınmıştır. Bu dosyaların önemli bileşeni olan bilirkişi raporları ve ekleri detaylı olarak incelenmiştir. Buna göre her dava türüne göre ihtiyaç duyulan gayrimenkule ilişkin bilgi ve belgeler Tablo 4' da sunulmuştur.

Tablo 4'de görüleceği üzere; incelenen dava türlerinin tamamında taşınmazın konumu, cinsi, yüzölçümü vb. mülkiyete ilişkin verilere ihtiyaç duyulmaktadır. Kuşkusuz tapu kaydı bu ihtiyaçları tek başına karşılayacaktır. Taşınmaza ilişkin pafta örneği, koordinat listesi vb. teknik belgeler ise kadastro arşivinden elde edilecek rasatlar veya çeşitli belgelerle sunulabilir. Vergi beyanı ve imar durumuna ilişkin belgeler ise belediye/il özel idareleri tarafından arşivlenmektedir. Bu belgelere ek olarak; davanın niteliğine göre şu belgelere de ihtiyaç duyulabilir.

- El atmanın önlenmesi davalarında; taşınmazın arsa değeri, işgale uğrayan alan hesabını gösterir belge, ecri misil tazminat hesabını gösterir belge, kıyı kenar çizgisi tespiti verileri, amenajman planı, kapitalizasyon faiz oranı, taşınmazın yapı alanı, sınıfı, değeri vb.

- Kadastro davalarında; kıyı kenar çizgisi tespiti verileri, amenajman planı,

- Kamulaştırma davalarında; alternatif emsal taşınmaz araştırması, emsal taşınmazlarla mukayese, emsal mukayesesinin taşınmaz değerleme kriterleri ile yapılması, taşınmazın arsa değeri, işgale uğrayan alan hesabını gösterir belge, hak tesisi kurulabilecek güzergâhlar, kıyı kenar çizgisi tespiti verileri, amenajman planı, kapitalizasyon faiz oranı, taşınmazın yapı alanı, sınıfı, değeri vb. bilgi ve belgeler, 
Tablo 4. Gayrimenkul davalarında bilirkişi raporlarında yer alan belgeler

\begin{tabular}{|c|c|c|c|c|c|c|c|c|c|c|c|c|c|c|c|c|}
\hline Belgeler & 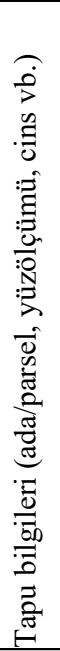 & 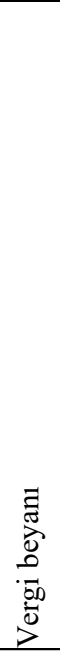 & 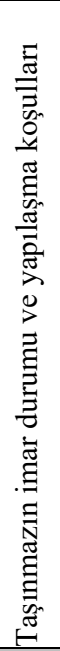 & 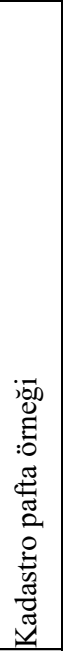 & 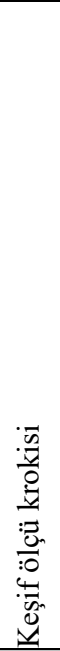 & 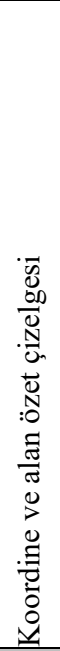 & 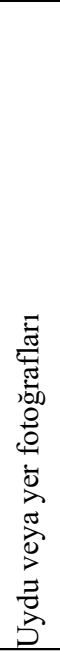 & 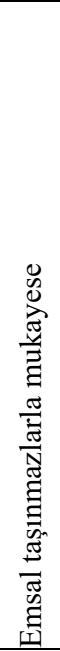 & 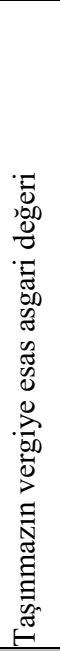 & 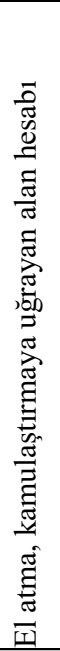 & 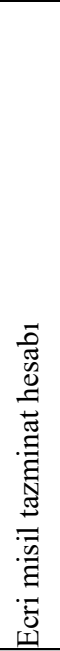 & 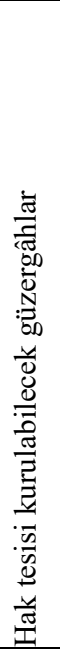 & 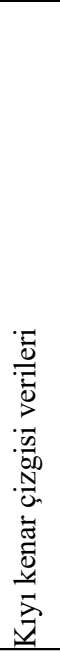 & 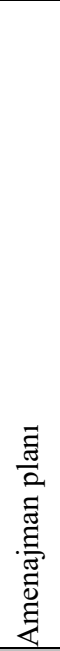 & 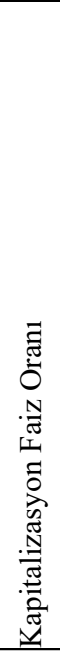 & 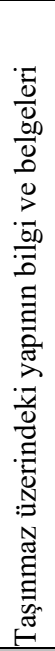 \\
\hline El atmanın önlenmesi & & & & & & & & & & & & & & & & \\
\hline Kadastro & & & & & & & & & & & & & & & & \\
\hline Kamulaştırma & & & & & & & & & & & & & & & & \\
\hline Kat Mülkiyeti & & & & & & & & & & & & & & & & \\
\hline $\begin{array}{l}\text { Tapu İptali ve tescil } \\
\text { (kadastro) }\end{array}$ & & & & & & & & & & & & & & & & \\
\hline $\begin{array}{l}\text { Tapu iptali ve tescil } \\
\text { (orman) }\end{array}$ & & & & & & & & & & & & & & & & \\
\hline $\begin{array}{l}\text { Tapu iptali ve tescil } \\
\text { (k1y1) }\end{array}$ & & & & & & & & & & & & & & & & \\
\hline İmar & & & & & & & & & & & & & & & & \\
\hline $\begin{array}{l}\text { Ayni/şahsi hakların } \\
\text { tesisi }\end{array}$ & & & & & & & & & & & & & & & & \\
\hline $\begin{array}{l}\text { Taşkın inşaat } \\
\text { nedeniyle tazminat }\end{array}$ & & & & & & & & & & & & & & & & \\
\hline Ortaklığın giderilmesi & & & & & & & & & & & & & & & & \\
\hline
\end{tabular}

- Kat mülkiyeti davalarında; taşınmazın KM anındaki 3D yapılaşma durumu, değerini etkileyecek faktörler ve bunların ağırlıklandırılması, arsa payı hesabı, yap1 hesab1, yap1 yıpranma pay1, bağımsız bölüm rayiç değeri,

- Tapu iptali ve tescil (orman) davalarında; amenajman planı,

- Tapu iptali ve tescil (kıyı kenar)davalarında; kıyı kenar çizgisi tespiti verileri,

- Ayni/şahsi hakların tesisi davalarında; işgale uğrayan alan hesabını gösterir belge, ecri misil tazminat hesabını gösterir belge, hak tesisi kurulabilecek güzergâhlar,

- Taşkın inşaat nedeniyle tazminat davalarında; işgale uğrayan alan hesabını gösterir belge, ecri misil tazminat hesabını gösterir belge, kapitalizasyon faiz oranı, taşınmazın yapı alanı, sınıfı, değeri vb. bilgi ve belgeler,

- İzale-i şüyu davalarında; taşınmazın arsa değeri, taşınmazın yapı alanı, sınıfı, değeri vb. bilgi ve belgeler bilirkişi raporlarına dâhil edilmektedir. 


\subsection{Anket sonuçları}

Anket çalışması ile aktif bilirkişilik yapan veya yapabilecek kişiler ile dava konuları arasındaki ilişki tespit edilmeye çalışılmıştır. "Dava-Taşınmaz-Meslek Disiplinlerinin Araştırılması" başlı̆̆ı altında hazırlanan ilk anket formu ile taşınmaz tabanlı davalarda bilirkişi olarak görev yapmış/yapabilecek çeşitli meslek kollarından çalışanlara çeşitli sorular yöneltilmiş ve yanıtlar üzerinde analizler yapılmıştır. 78 kişiden oluşan örneklem grubunun unvan ve mezuniyet durumu Tablo 5'de, mesleki deneyim ve bilirkişi raporu düzenleme sıklı̆̆ı Tablo 6' da sunulmuştur.

Tablo 5. Katılımcıların unvan ve mezun olunan fakülte/bölümlere göre dağılımı

\begin{tabular}{|c|c|c|c|c|c|c|c|c|c|c|c|c|c|c|}
\hline Unvanlar & $\frac{\sqrt{2}}{\sqrt[0]{2}}$ & $\begin{array}{l}\ddot{0} \\
\dot{\Xi} \\
\stackrel{0}{0}\end{array}$ & 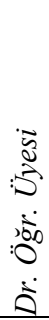 & 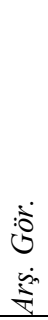 & 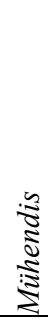 & 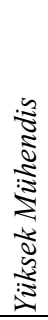 & 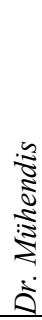 & 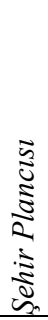 & 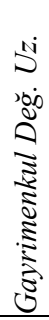 & \begin{tabular}{c}
$\vdots$ \\
\multirow{N}{N}{} \\
$S$
\end{tabular} & $\begin{array}{l}\tilde{\tilde{U}} \\
: \\
:\end{array}$ & $\frac{\sqrt{\frac{9}{2}}}{\frac{3}{2}}$ & 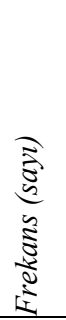 & $\begin{array}{l}\frac{7}{2} \\
\frac{1}{2} \\
\int^{2} \\
\end{array}$ \\
\hline İnşaat Müh. & 3 & & 2 & 1 & 7 & 1 & 1 & & & & & & 15 & 19 \\
\hline Harita Müh. & & 1 & 1 & 1 & 4 & 4 & & & 2 & & & & 13 & 16 \\
\hline İktisadi ve İdari Bilimler (İ̈B) & 3 & & 3 & & & & & & 1 & 2 & & 1 & 10 & 13 \\
\hline Orman Müh. & 4 & 2 & 1 & & & & & & & & & & 7 & 9 \\
\hline Jeoloji Müh. & 5 & & & & & & 1 & & & & & & 6 & 8 \\
\hline Jeofizik Müh. & 3 & 1 & 1 & 1 & & & & & & & & & 6 & 8 \\
\hline Mimarlık & 2 & & 2 & & & & & & & & & & 4 & 5 \\
\hline Çevre Müh. & 1 & 1 & & 2 & & & & & & & & & 4 & 5 \\
\hline Şehir ve Bölge Planlama & & 1 & 1 & & & & & 1 & & & & & 3 & 4 \\
\hline Makina Müh. & 1 & & 1 & & 1 & & & & & & & & 3 & 4 \\
\hline Ziraat Fakültesi & & 1 & & & 1 & & & & & & & & 2 & 3 \\
\hline Endüstri Müh. & & & & & & & & & & & 1 & & 1 & 1 \\
\hline İşletme Müh. & 1 & & & & & & & & & & & & 1 & 1 \\
\hline Metalürji Müh. & 1 & & & & & & & & & & & & 1 & 1 \\
\hline Veterinerlik & & & 1 & & & & & & & & & 1 & 2 & 3 \\
\hline Frekans (sayl) & 24 & 7 & 13 & 5 & 13 & 5 & 2 & 1 & 3 & 2 & 1 & 2 & 78 & 100 \\
\hline Yüzde (\%) & 31 & 9 & 17 & 6 & 16 & 6 & 3 & 1 & 4 & 3 & 1 & 3 & 100 & \\
\hline
\end{tabular}

Tablo 6. Katılımcıların mesleki deneyimleri (a) ve bilirkişi raporu düzenleme sıklığı (b)

\begin{tabular}{|c|c|c|c|c|c|}
\hline Deneyim (yıl) & Frekans (Sayı) & Yüzde (\%) & Rapor Sayıs & Frekans (Sayl) & Yüzde (\%) \\
\hline 10 yıla kadar & 12 & 15,4 & 20 ye yakın & 12 & 30,0 \\
\hline 10-19 y1l aras1 & 26 & 33,3 & $20-50$ aras1 & 6 & 15,0 \\
\hline $20-29$ y1l aras1 & 23 & 29,5 & $50-100$ aras1 & 5 & 12,5 \\
\hline 30 yıl ve üzeri & 17 & 21,8 & 100 ve üzeri & 17 & 42,5 \\
\hline Toplam & 78 & 100,0 & TOPLAM & 40 & 100,0 \\
\hline \multicolumn{3}{|c|}{ (a) } & \multicolumn{3}{|c|}{ (b) } \\
\hline
\end{tabular}

Geliştirilen ankette örneklem grubuna, sizce, mesleki disiplininiz aşă̆ıda türleri verilen arsa arazi - bina nitelikli taşınmaz mallara ilişkin davaların hangilerinde bilirkişi olarak görev alabilir?' sorusu yönelmiştir. Böylece, meslek disiplini ile gayrimenkul sınıfı arasındaki ilişki tespit edilerek, meslek disiplinlerinin hangi gayrimenkul davalarında bilirkişi olarak görev alabileceği analiz 
edilmiştir. Gayrimenkule yönelik her bir davada, arazi, arsa veya binalar davaya konu olabilmektedir. Örneğin tarım arazisine yönelik değer tespitinde ziraat mühendisliği aktif rol alırken, yap1 değerlemesinde inşaat mühendisliği daha aktif olabilmektedir. $\mathrm{Bu}$ ve benzeri bilirkişilik hizmet alımlarında zaman zaman kargaşa ortaya çıkabilmektedir. Meslek disiplinlerinin ilgi alanını netleştirmek açısından yöneltilen anket sorusunun sonuçları Tablo 7 'de sunulmuştur. Birden çok dava türü sorulduğu için katılımcılar her bir dava türü için; arazi, arsa ve bina nitelikli taşınmazların kendi disiplinlerine uygunluğunu cevaplamıştır.

Tablo 7. Gayrimenkulün niteliğine göre mesleklerin dağılımı

\begin{tabular}{|l|c|c|c|c|}
\hline Meslek Disiplini & Arazi & Arsa & Bina & Toplam \\
\hline Harita Mühendisi & 401 & 399 & 232 & 1032 \\
\hline İnşaat Mühendisi & 139 & 229 & 282 & 649 \\
\hline Şehir ve Bölge Planc1 & 76 & 76 & 76 & 228 \\
\hline İ̈BF Mezunu & 41 & 39 & 27 & 107 \\
\hline Orman Mühendisi & 50 & 14 & 0 & 62 \\
\hline Mimar & 2 & 6 & 47 & 55 \\
\hline Teknisyen (TKGM) & 11 & 11 & 10 & 33 \\
\hline Ziraat Mühendisi & 24 & 0 & 0 & 24 \\
\hline Makine Mühendisi & 8 & 9 & 6 & 23 \\
\hline Jeoloji Mühendisi & 15 & 0 & 0 & 15 \\
\hline Jeofizik Mühendisi & 3 & 3 & 3 & 9 \\
\hline Çevre Mühendisi & 1 & 1 & 0 & 2 \\
\hline
\end{tabular}

Tablo 7 sunulan sonuçlara göre şu değerlendirmeler yapılabilir. Farklı disiplinden olan örneklem grubu birbirinin mesleğini bazı davalarda ön plana çıkartmış durumdadır. Örnek olarak sadece iki katılımcının olduğu ziraat mühendisliği mezununa rağmen, arazi nitelikli davalarda ziraat mühendisi ve jeoloji mühendisi olması gerekliliği açık bir şekilde ifade edilmiştir. İİB mezunu kişilerin her üç taşınmaz türünde de bilirkişi olarak görev alması gerektiği ifade edilmiştir. Ancak arsa ve bina nitelikli taşınmazlarda ziraat mühendisinin olmaması gerektiği de yine örneklem grubunun yanıtlarından anlaşılmaktadır. Hatta ziraat mühendisi olan iki katılımcı dahi arsa ve bina nitelikli davalarda görev alma noktasında görüş ifade etmemişlerdir. Bina nitelikli taşınmazların analizinde ise ön plana inşaat mühendisi ve mimar olan bilirkişiler çıkmaktadır. Orman mühendisi bilirkişiler arazi nitelikli taşınmaz davalarında yoğun olarak ön plana çıkmışken, arsa nitelikli taşınmaz davalarında kısmen ön plandadırlar. Ancak, bina nitelikli taşınmaz davalarında hiç yer etmemişlerdir. Arazi, arsa ve bina nitelikli taşınmaz davalarında inşaat mühendisi bilirkişilerin ağırlı̆̆ı ise sıralı bir şekilde artmaktadır. Arazi, arsa ve bina nitelikli taşınmaz davalarında harita mühendisi bilirkişilerin ağırlığı ise farklılık göstermektedir. Arsa ve arazide üst seviyede olan harita 
mühendisi bilirkişi olması gerekliliği, bina nitelikli taşınmazlara ilişkin davalarında iyice azalmaktadir.

Örneklem grubuna yöneltilen diğer soru ile bazı meslek disiplinleri 41 farklı gayrimenkul davaları arsında ki ilişki ortaya konulmuştur. Bu soruya yanıt veren meslek disiplini mensubu olan örneklem gruplarının yanıtları dikkate alınarak yüzde gösterimler sunulmuştur. Elde edilen sonuçlar Tablo 8'de sunulmuştur.

Tablo 8. Katılımcı yanıtlarının meslek disiplinleri açısından analiz tablosu.

\begin{tabular}{|c|c|c|c|c|c|c|c|c|c|c|c|c|}
\hline \multicolumn{5}{|l|}{$\begin{array}{l}\text { HM: Harita Mühendisi } \\
\text { ŞBP: Şehir ve Bölge Plancısı }\end{array}$} & \multicolumn{8}{|c|}{$\begin{array}{l}\text { İBF: İktisadi ve İdari Bilimler Fak. Mezunu } \\
\text { IM: Inşaat Mühendisi }\end{array}$} \\
\hline \multirow{2}{*}{$\begin{array}{l}\text { Davanin niteliği } \\
\text { Konusu }\end{array}$} & \multicolumn{4}{|c|}{ Arazi (\%) } & \multicolumn{4}{|c|}{$\operatorname{Arsa}(\%)$} & \multicolumn{4}{|c|}{ Bina (\%) } \\
\hline & $\mathrm{HM}$ & İM & İं̈BF & ŞBP & $\mathrm{HM}$ & İM & İİBF & ŞBP & $\mathrm{HM}$ & İM & İİBF & ŞBP \\
\hline Arsa Payının Düzeltilmesi İstemi & 92 & 27 & 10 & 67 & 92 & 40 & 10 & 67 & 46 & 53 & 10 & $67 \%$ \\
\hline $\begin{array}{l}\text { Arsa Paylarının Düzeltilmesi ve } \\
\text { Denkleştirme Davası }\end{array}$ & 85 & 33 & 10 & 67 & 85 & 40 & 10 & 67 & 46 & 40 & 10 & $67 \%$ \\
\hline Aynen İfa İstemi & 62 & 7 & & 33 & 62 & 27 & & 33 & 31 & 27 & & $33 \%$ \\
\hline $\begin{array}{l}\text { Bağımsız Bölüm Üzerindeki Müdahalenin } \\
\text { Önlenmesi Davası }\end{array}$ & 62 & 20 & & 67 & 62 & 33 & & 67 & 38 & 53 & & 67 \\
\hline $\begin{array}{l}\text { Bağımsız Bölümden Geçilmesine İzin } \\
\text { Verilmesi Davası }\end{array}$ & 54 & 27 & & 67 & 54 & 33 & & 67 & 46 & 47 & & 67 \\
\hline Ecrimisil (Haksı İşgal) Davası & 77 & 33 & 10 & 67 & 69 & 60 & 10 & 67 & 38 & 60 & 10 & 67 \\
\hline El Atmanın Önlenmesi & 85 & 27 & 10 & 33 & 85 & 40 & 10 & 33 & 38 & 53 & 10 & 33 \\
\hline $\begin{array}{l}\text { Geçit, Mecra vb. ayni/şahsi hakkın } \\
\text { kurulması Davası }\end{array}$ & 85 & 27 & 10 & 67 & 85 & 47 & 10 & 67 & 38 & 40 & & 67 \\
\hline $\begin{array}{l}\text { Gider ve Avans Payını Ödemeyen Kat } \\
\text { Maliki Hakkında Dava }\end{array}$ & 38 & 7 & 10 & & 31 & 27 & 10 & & 23 & 53 & 10 & \\
\hline Hatalı Hisse Payı (Bağımsız Bölümde) & 85 & 13 & 10 & 67 & 85 & 20 & 10 & 67 & 46 & 40 & & 67 \\
\hline İmar Planı Değişikliği & 77 & 20 & 10 & 100 & 77 & 33 & 10 & 100 & 46 & 20 & 10 & 100 \\
\hline İmar Uygulaması & 85 & 27 & 10 & 100 & 85 & 40 & 10 & 100 & 38 & 33 & 10 & 100 \\
\hline İnşaatın Kaldırılması Talebi & 46 & 20 & & 100 & 46 & 47 & & 100 & 38 & 67 & & 100 \\
\hline İrtifakın Terkinin İstemi & 69 & 13 & & 67 & 69 & 33 & & 67 & 38 & 33 & & 67 \\
\hline Kadastro (Tespit davas1) & 85 & 7 & & 33 & 85 & 13 & & 33 & 38 & 20 & & 33 \\
\hline $\begin{array}{l}\text { Kadastro (Yenileme ve teknik hata } \\
\text { düzeltme) }\end{array}$ & 85 & 13 & 10 & 33 & 85 & 20 & & 33 & 46 & 20 & 10 & 33 \\
\hline $\begin{array}{l}\text { Kamulaştırılan Taşınmazın Geri Alınması } \\
\text { Davası }\end{array}$ & 85 & 33 & 10 & 67 & 85 & 53 & 10 & 67 & 46 & 53 & 10 & 67 \\
\hline Kamulaştırma (Bedel) & 77 & 53 & 30 & 100 & 77 & 67 & 40 & 100 & 46 & 67 & 20 & 100 \\
\hline Kamulaştırma (Kamu Yararı) & 77 & 53 & 20 & 100 & 77 & 47 & 20 & 100 & 38 & 73 & & 100 \\
\hline $\begin{array}{l}\text { Kamulaştırmasız El Atma(Hukuki El } \\
\text { Atma) }\end{array}$ & 85 & 33 & 20 & 100 & 85 & 53 & 20 & 100 & 46 & 60 & 10 & 100 \\
\hline $\begin{array}{l}\text { Kamulaştırmasız El Atma(Kal-Yıkım } \\
\text { Davası) }\end{array}$ & 77 & 27 & 20 & 100 & 77 & 47 & 20 & 100 & 46 & 60 & 10 & 100 \\
\hline $\begin{array}{l}\text { Kamulaştırmasız El Atma(Men'i } \\
\text { Müdahale Davası) }\end{array}$ & 85 & 33 & 20 & 100 & 85 & 47 & 20 & 100 & 46 & 60 & 10 & 100 \\
\hline $\begin{array}{l}\text { Kamulaştırmasız El Atma(Tazminat } \\
\text { Davası) }\end{array}$ & 62 & 33 & 20 & 33 & 85 & 47 & 10 & 33 & 46 & 60 & 10 & 33 \\
\hline Kat Mülkiyetinin Devri İstemi & 62 & 13 & 20 & 33 & 62 & 20 & 20 & $33 \%$ & 38 & 47 & 20 & 33 \\
\hline Kat Mülkiyetinin Kurulması İstemi & 77 & 13 & 10 & 67 & 62 & 27 & 10 & 67 & 38 & 53 & 10 & 67 \\
\hline $\begin{array}{l}\text { Maliklerin Haklarına Karşı Yapılan } \\
\text { Tecavüzün Önlenmesi Davası }\end{array}$ & 77 & 27 & 30 & 67 & 77 & 53 & 20 & 67 & 46 & 53 & 20 & 67 \\
\hline Ortak Yere El Atmanın Önlenmesi İstemi & 77 & 20 & 20 & 67 & 77 & 40 & 20 & 67 & 46 & 47 & 10 & 67 \\
\hline Ortaklığın Giderilmesi Davası & 85 & 27 & 20 & 67 & 85 & 47 & 20 & 67 & 46 & 53 & 10 & 67 \\
\hline $\begin{array}{l}\text { Satış Akdinin Feshi ve Tapu İptali Davası } \\
\text { (Kat Karşılığı İnşaat Sözleşmesi, } \\
\text { Muvazaalı Satış İşlemi vs.) }\end{array}$ & 77 & 20 & 10 & 33 & 77 & 53 & 10 & 33 & 46 & 53 & 10 & 33 \\
\hline Şüfa Hakkı Davası & 69 & 13 & & 67 & 69 & 40 & & 67 & 46 & 47 & & 67 \\
\hline Tahliye Davası & 69 & 13 & 10 & 33 & 69 & 33 & 10 & 33 & 38 & 40 & 10 & 33 \\
\hline
\end{tabular}




\begin{tabular}{|l|l|l|l|l|l|l|l|l|l|l|l|l|}
\hline $\begin{array}{l}\text { Tapu İptali, Tapu İptali ve Tescil } \\
\text { (Kadastro) }\end{array}$ & 85 & 20 & & 67 & 85 & 40 & & 67 & 54 & 53 & & 67 \\
\hline Tapu İptali, Tapu İptali ve Tescil (Kıyı) & 92 & 20 & 10 & 67 & 92 & 33 & 10 & 67 & 54 & 47 & & 67 \\
\hline Tapu İptali, Tapu İptali ve Tescil (Orman) & 92 & 20 & & & 92 & 27 & & 67 & 54 & 40 & & 67 \\
\hline Tapu İşleminin İptali İstemi & 85 & 33 & 10 & 67 & 85 & 33 & & 67 & 54 & 47 & & 67 \\
\hline $\begin{array}{l}\text { Tapu Sicilinin Tutulmasından Doğan } \\
\text { Zararların Tazmini Davası }\end{array}$ & 77 & 13 & & 33 & 77 & 20 & & 33 & 54 & 27 & & 33 \\
\hline Tashih Davaları & 69 & & & 33 & 69 & & & 33 & 54 & 13 & & 33 \\
\hline Taşkı İnşaat Nedeniyle Tazminat Davası & 69 & 40 & & 67 & 69 & 53 & & 67 & 38 & 67 & & 67 \\
\hline Tazminat Davası & 62 & 20 & 30 & 33 & 62 & 40 & 30 & 33 & 38 & 47 & 30 & 33 \\
\hline Tenkis Davası & 69 & 13 & & 33 & 69 & 27 & & 33 & 38 & 27 & & 33 \\
\hline Vakıf Şerhi ve Taviz Bedeli Davası & 69 & 13 & & 67 & 69 & 27 & & 67 & 46 & 27 & & 67 \\
\hline
\end{tabular}

Tablo 8 incelendiğinde, davanın ve taşınmazın özelliğine göre bilirkişilerin mutlak suretle değişmesi gerektiği görülmektedir.

$\mathrm{Bu}$ tablodan birkaç örnek vererek tablo yorumlanmıştır. Özellikli örneklem grubu bazı sorularda kendi disiplinini ön plana çıkartmıştır. Bu tabloda çok dikkat çeken bu tip değerlendirmeler kırmızı renkli olarak vurgulanmıştır. Bağımsız Bölüm Üzerindeki Müdahalenin Önlenmesi Davasının şehir plancısı ile ortalama \%67 oranında ilişkilendirilmiş olması dikkat çekmektedir. Benzer bir durum ise arazi, arsa ve bina ayrımı gözetmeksizin; Kamulaştırma (Bedel), Kamulaştırma (Kamu Yararı), Kamulaştırmasız El Atma (Hukuki El Atma), Kamulaştırmasız El Atma (Kal-Yıkım Davası), Kamulaştırmasız El Atma (Men'i Müdahale Davası) davaları ile şehir plancısının \%100 ilişkili çıkmasıdır.

$\mathrm{Bu}$ tip aşırı farklılıklar yanında, tablodan genel anlamda şu sonuç çıkartılmıştır. Davanın konusu olan taşınmazın özelliğine göre farklı disiplinler ön plana çıkmalıdır. Buna rağmen salt bir alanının tek başına karar vermesi pek mümkün değerlendirilmemiştir. Diğer uzmanlık alanlarının az da olsa mutlaka katkı sunması beklentisi mevcuttur.

\subsection{Lisans Düzeyinde Okutulan Dersler ile Dava Konularının İlişkilendirilmesi}

Çalışmanın bu bölümü, taşınmaz tabanlı davalarda bilirkişi olarak görev alabilecek meslek disiplinlerinde lisans düzeyinde okutulan zorunlu/seçmeli derslerin temel gayrimenkul dava konuları ile ilişkisini, her bir meslek disiplini için ayrı ayrı hazırlanan anket formlarına verilen yanıtlar üzerinden irdeleme üzerine inşa edilmiştir. Harita/Geomatik Mühendisliği bölümü akademik personelleri ile elektronik posta aracılığı ile iletişim kurulabilen üniversitelerin listesi, Tablo 9 ile verilmiştir. Çalışma kapsamında 22 üniversitenin ilgili bölümlerinin akademik personellerine başvurulmuştur. 
Tablo 9. Harita/Geomatik Mühendisliğine sahip, çalışmaya konu üniversiteler

\begin{tabular}{|l|l|l|}
\hline Afyon Kocatepe Üniversitesi & *Harran Üniversitesi & $\begin{array}{l}\text { *Niğde Ömer Halisdemir } \\
\text { Üniversitesi }\end{array}$ \\
\hline Aksaray Ü. & *Istanbul Teknik Ü. & *Osmaniye Korkut Ata Ü. \\
\hline *Artvin Çoruh Ü. & *İzmir Katip Çelebi Ü. & Sivas Cumhuriyet Ü. \\
\hline $\begin{array}{l}\text { *Çanakkale On Sekiz Mart } \\
\text { Ü. }\end{array}$ & *Karadeniz Teknik Ü. & *Tokat Gaziosmanpaşa Ü. \\
\hline *Erciyes Ü. & *Kocaeli Ü. & Uşak Ü. \\
\hline Gebze Teknik Ü. & Konya Teknik Ü. & Y1ldız Teknik Ü. \\
\hline *Gümüşhane Ü. & *Necmettin Erbakan Ü. & *Zonguldak Bülent Ecevit Ü. \\
\hline *Hacettepe Ü. & *Ankete HM bölümünden katılım sağlayan üniversiteler \\
\cline { 2 - 3 }
\end{tabular}

KTÜ Harita Mühendisliği bünyesinde arazi yönetimi ile ilişkili yedi zorunlu ve 17 seçmeli dersin yanında Harita Mühendisliği bölümüne sahip başka üniversitelerde zorunlu olarak okutulan Arazi Yönetimi ve Kamu Ölçmeleri derslerinin temel gayrimenkul dava konuları ile ilişkisini gösteren Tablo 10 aşağıda sunulmuştur.

Dava konuları özelinde bakıldığında katılımcılar, lisans düzeyinde okutulan dersler ile en fazla sırasıyla kamulaştırma, imar uygulamaları ve planlama konuları arasında ilişki olduğuna işaret ederken en az sirasıla mimari proje uygulamalar, toprak bilgisi ve ecri-misil konuları arasında bağlantı olduğunu düşünmektedir.

Zorunlu derslere ait veriler incelendiğinde en fazla payın toplam 234 işaretleme ile Taşınmaz Mal Hukuku, en az payın ise toplam 114 işaretleme ile Kamu Ölçmeleri dersine ait olduğu saptanmıştır. Diğer zorunlu dersler ise Bölge ve Şehir Planlama (208 işaretleme), Kadastro Bilgisi (198 işaretleme), Kentsel Alan Düzenlemesi (191 işaretleme), Kırsal Alan Düzenlemesi (181 işaretleme), Taşınmaz Değerlemesi (170 işaretleme), Proje Planlaması (127 işaretleme), Arazi yönetimi (117 işaretleme) şeklinde sıralanmaktadır.

Tablo 10. Harita Mühendisliği lisans dersleri-gayrimenkul dava konuları ilişkisi

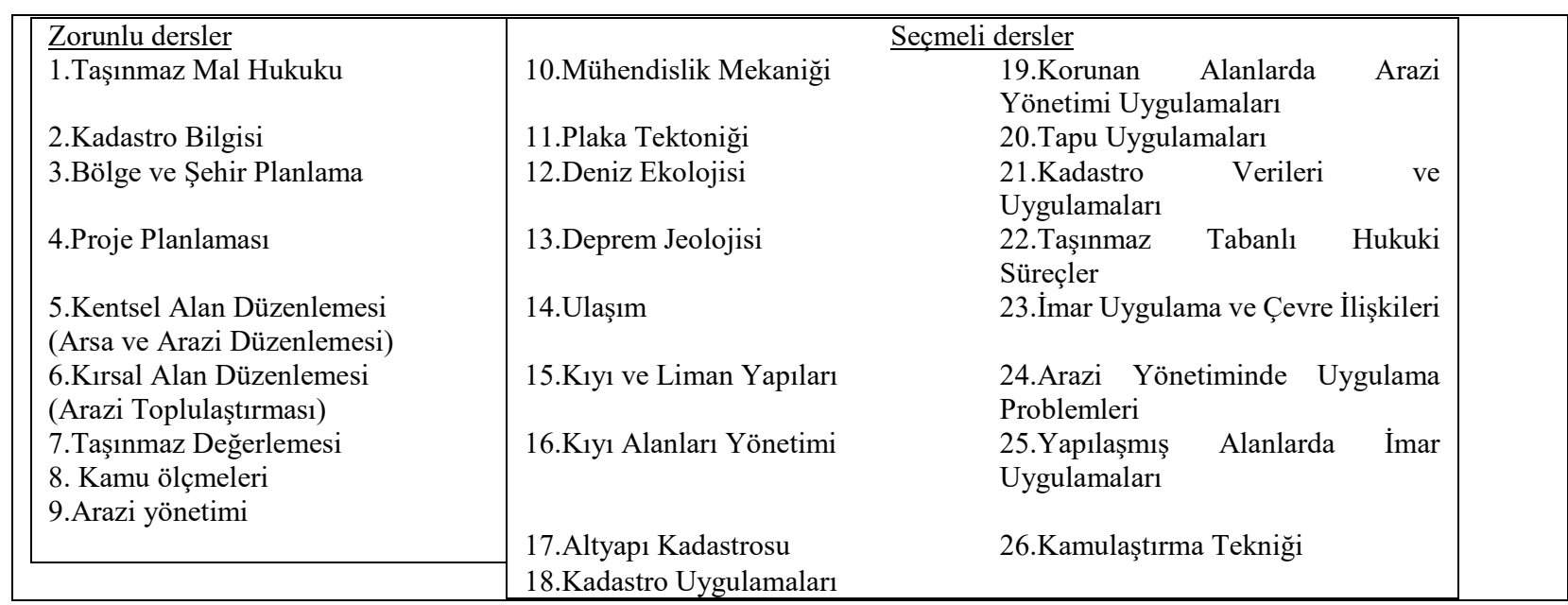




\begin{tabular}{|c|c|c|c|c|c|c|c|c|c|c|c|c|c|c|c|c|c|c|c|}
\hline $\begin{array}{r}\text { Dava } \\
\text { Konusu }\end{array}$ & 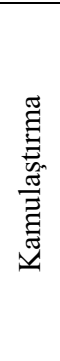 & 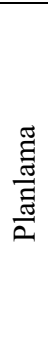 & 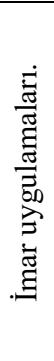 & 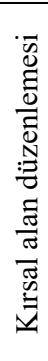 & 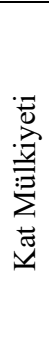 & 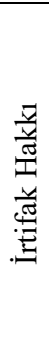 & $\underset{\overrightarrow{0}}{\overrightarrow{0}}$ & 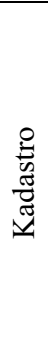 & 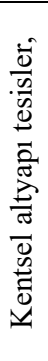 & 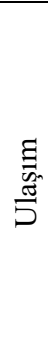 & 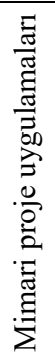 & 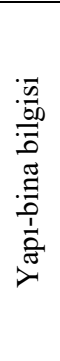 & 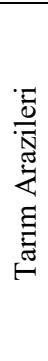 & 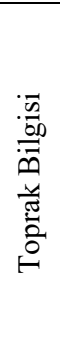 & 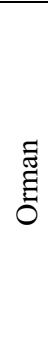 & 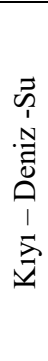 & 瑟 & 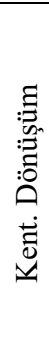 & 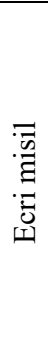 \\
\hline 1 & 23 & 6 & 12 & 14 & 21 & 19 & 25 & 18 & 6 & 4 & 4 & 9 & 10 & 5 & 12 & 9 & 5 & 12 & 19 \\
\hline 2 & 15 & 6 & 12 & 9 & 11 & 13 & 19 & 23 & 6 & 5 & 6 & 4 & 12 & 3 & 17 & 14 & 2 & 7 & 12 \\
\hline 3 & 10 & 21 & 17 & 6 & 5 & 5 & 17 & 4 & 17 & 18 & 14 & 12 & 4 & 3 & 7 & 12 & 12 & 18 & 3 \\
\hline 4 & 6 & 16 & 8 & 6 & 3 & 2 & 5 & 3 & 10 & 11 & 8 & 6 & 5 & 3 & 3 & 5 & 11 & 11 & 1 \\
\hline 5 & 18 & 19 & 18 & 3 & 10 & 12 & 1 & 7 & 19 & 13 & 12 & 11 & 1 & 3 & 3 & 4 & 11 & 18 & 3 \\
\hline 6 & 16 & 17 & 9 & 21 & 1 & 10 & 9 & 8 & & 9 & 2 & 1 & 21 & 21 & 14 & 4 & 7 & 2 & 3 \\
\hline 7 & 14 & 6 & 9 & 7 & 11 & 11 & 9 & 11 & 8 & 9 & 10 & 16 & 7 & 6 & 4 & 5 & 5 & 9 & 6 \\
\hline 8 & 11 & 7 & 11 & 7 & 5 & 6 & 11 & 8 & 5 & 5 & 2 & 2 & 5 & 2 & 5 & 5 & 1 & 4 & 4 \\
\hline 9 & 8 & 9 & 8 & 10 & 4 & 6 & 6 & 8 & 5 & 4 & 2 & 1 & 8 & 4 & 5 & 6 & 3 & 7 & 4 \\
\hline 10 & & & & & & & 7 & & 1 & 4 & 1 & 4 & & & & & & 1 & \\
\hline 11 & 1 & 2 & 2 & & & & & 1 & 1 & 2 & & 2 & & 1 & & & 1 & 1 & \\
\hline 12 & 1 & 1 & & 1 & & & 1 & & & 1 & & 1 & & 1 & & 9 & 4 & & \\
\hline 13 & & 2 & 2 & & & & & & 1 & 2 & & 3 & & & & 1 & 4 & 1 & \\
\hline 14 & 4 & 5 & 3 & 5 & & 2 & & & 6 & 9 & 2 & 1 & 1 & 1 & 1 & 1 & 2 & 2 & \\
\hline 15 & & 4 & 1 & & & & 1 & 1 & 1 & 4 & 1 & 3 & & & & 7 & 3 & & \\
\hline 16 & 3 & 5 & 3 & 2 & & 2 & 1 & 4 & & 3 & 1 & 1 & 1 & 2 & 2 & 8 & 4 & 3 & 1 \\
\hline 17 & 3 & 4 & 4 & 3 & 1 & 5 & 1 & 8 & 8 & 4 & 3 & 2 & & & & 1 & 2 & 3 & 1 \\
\hline 18 & 8 & 5 & 5 & 5 & 7 & 4 & 2 & 9 & 4 & 1 & 1 & 2 & 6 & 5 & 6 & 4 & 3 & 4 & 5 \\
\hline 19 & 5 & 8 & 6 & 5 & 1 & 1 & 8 & 5 & 2 & 2 & 1 & 2 & 6 & 4 & 4 & 2 & 7 & 5 & 4 \\
\hline 20 & 6 & 2 & 4 & 3 & 8 & 8 & 4 & 6 & 1 & 1 & 1 & 2 & 4 & 1 & 2 & 2 & 2 & 6 & 4 \\
\hline 21 & 7 & 3 & 5 & 7 & 7 & 8 & 9 & 10 & 4 & 1 & 2 & 2 & 5 & 4 & 7 & 3 & 2 & 5 & 6 \\
\hline 22 & 8 & 5 & 10 & 6 & 10 & 7 & 9 & 8 & 3 & 2 & 2 & 3 & 4 & 2 & 4 & 4 & 5 & 8 & 5 \\
\hline 23 & 5 & 5 & 11 & 3 & 2 & 1 & 8 & 4 & 4 & 3 & 1 & 2 & 2 & 2 & 2 & 3 & 8 & 5 & 3 \\
\hline 24 & 6 & 7 & 6 & 9 & 4 & 4 & 1 & 8 & 6 & 5 & 1 & 2 & 8 & 7 & 6 & 5 & 6 & 6 & 3 \\
\hline 25 & 8 & 8 & 10 & & 8 & 6 & 4 & 6 & 7 & 4 & 1 & 7 & & & 1 & 1 & 2 & 9 & 2 \\
\hline 26 & 11 & 5 & 7 & 7 & 4 & 5 & 6 & 5 & 5 & 4 & 5 & 1 & 7 & 3 & 2 & 1 & 2 & 4 & 2 \\
\hline Toplam & $\begin{array}{l}19 \\
7\end{array}$ & $\begin{array}{l}17 \\
8\end{array}$ & $\begin{array}{ll}18 \\
3\end{array}$ & $\begin{array}{l}13 \\
9\end{array}$ & $\begin{array}{l}12 \\
3\end{array}$ & $\begin{array}{l}13 \\
7\end{array}$ & $\begin{array}{ll}16 \\
4\end{array}$ & $\begin{array}{l}16 \\
5\end{array}$ & $\begin{array}{l}13 \\
0\end{array}$ & $\begin{array}{l}13 \\
0\end{array}$ & 83 & $\begin{array}{l}10 \\
2\end{array}$ & $\begin{array}{l}11 \\
7\end{array}$ & 83 & $\begin{array}{l}10 \\
7\end{array}$ & $\begin{array}{l}11 \\
6\end{array}$ & $\begin{array}{l}11 \\
4\end{array}$ & $\begin{array}{l}15 \\
1\end{array}$ & 91 \\
\hline
\end{tabular}

Yukarıda ifade edilen ilişkiyi ortaya koyan tablolar çalışmadaki tüm disiplinler için ayrı ayrı ele alınmıştır. Tüm detaylarının bu çalışmayı çok uzatacak olması nedeniyle sunulamamıştır. Anketin gönderildiği akademik personel taşınmaz tabanlı dava konuları ile bölümlerinde okutulmakta olan zorunlu ve seçmeli dersleri ilişkilendirmiştir. Bu şekilde tüm disiplinler için ders dava konusu ilişki matrisi ortaya konulmuştur.

Tablo 11. Ders ve dava konusu ilişki matrisi yapılan bölüm ve dersler

\begin{tabular}{|l|l|l|l|l|}
\hline Bölüm & $\begin{array}{l}\text { Katılan } \\
\text { Üniversite } \\
\text { Sayıs1 }\end{array}$ & $\begin{array}{l}\text { Öğretim } \\
\text { Elemanı } \\
\text { Sayıs1 }\end{array}$ & $\begin{array}{l}\text { Zorunlu } \\
\text { Ders } \\
\text { Sayıs1 }\end{array}$ & $\begin{array}{l}\text { Seçmeli } \\
\text { Ders } \\
\text { Sayıs1 }\end{array}$ \\
\hline Harita Mühendisliği & 15 & 29 & 9 & 17 \\
\hline İnşaat Mühendisliği & 29 & 50 & 12 & 15 \\
\hline Çevre mühendisliği & 22 & 56 & 8 & 9 \\
\hline Mimarlı & 12 & 19 & 16 & 13 \\
\hline Jeoloji mühendisliği & 11 & 34 & 6 & 5 \\
\hline Jeofizik mühendisliği & 4 & 14 & 9 & 2 \\
\hline Orman mühendisliği & 9 & 31 & 13 & 11 \\
\hline Şehir ve Bölge Planlama & 11 & 13 & 9 & 11 \\
\hline Ziraat fakültesi lisans & 12 & 20 & 18 & 11 \\
\hline Hukuk fakültesi lisans & 6 & 12 & 8 & 2 \\
\hline
\end{tabular}


Buradan elde edilen çıkarımlar, anketin yukarı bölümlerinden elde edilen, dava konusu disiplinler arası ilişkiler birlikte ele alınarak birlikte değerlendirilmiştir. Çok sayıda davanın mesleği ile arsa, arazi ve bina ayrımı görülmeksizin ilişkili olduğunu ortaya koyan örneklem grubu yanıtları bilinmektedir. Ancak bu mesleklerin lisans müfredatlarında okutulan dersler ile bu tip davalar arasında ilişki olmadığı akademisyenlere uygulanan anket sorularından ayrıca anlaşılmaktadır. Burada otaya çıkan ilginç çelişkilerin başında bu durum özellikle dikkat çekmektedir. Böylesi bir durumun bilirkişi atanmadan önce tespit edilmesi ve kişinin mesleki eğitiminde almış olduğu derslerin içeriklerinin dikkate alınarak sorgulanabildiği dinamik bir sistemi işaret etmektedir.

\subsection{Nesne Tabanlı Veri Modeli Geliştirilmesi}

Yukarıdaki tüm veriler 1şığında, semantik anlamda e-devletin diğer bileşenleri ile birlikte çalışabilir UYAP'a uyarlanabilir bir nesne tabanlı veri modeli tasarımı yapılması kararlaştırılmıştır. Geliştirilen 'gayrimenkul dava sürecinin use-case diyagramı ile gösterimi' Şekil 4'te sunulmuştur. Use-case diyagramları, dava sürecinde aktör, yani dava sürecinde olayları başlatan unsurlar ile sürece dâhil olan kurumlar arasındaki bağı yansıtmaktadır. Böylece sistem içerisinde sürece dâhil olan aktörlere ve kurumlara vakıf olunabilmektedir. Aynı zamanda dava sürecinde gereksinim duyulan verileri, hangi aktörlerin hangi kurumlardan ne şekilde temin etmesi gerektiğine ilişkin bağlantılar da rahatlıkla görülmektedir. Şöyle ki dava sürecinde veriye ihtiyaç duyan aktörleri, davacı, davalı, hâkim bilirkişi gibi bireyler oluştururken, verinin temini için Tapu Müdürlüğü, Kadastro Müdürlüğü, İmar Müdürlüğü vb. kurumlardan sağlanmaktadır. Veri alış-verişi haricinde aktörlerin sistem içerisinde hak, yetki ve görev tanımlarına rastlamak da mümkün olmaktadır. Dava süreci içerisinde hâkimin davayı kabul/red etme, ara karar, kesin karar, gerekçeli karar alma gibi fonksiyonları yürütür. Bilirkişilerin davaya atanması sonrası keşif, rapor hazırlama, talep halinde ek rapor hazırlama gibi görevleri yürütür. Taşınmazın ve davanın özelliğine göre bilirkişi seçimi de somut verilerle yapılabilir. Nitekim yükseköğretim sistemi üzerinden, bilirkişilerin uzmanlıkları, aldıkları dersler, derslerin haftalık içerikleri ve bilgi paketleri sorgulanabilir. Ayrıca, varsa yüksek lisans ve doktora gibi uzmanlık durumları da edinilebilir. Bilirkişi adaylarının mesleki gelişimlerine yönelik bilgilerinin de sorgulanması sayesinde en uygun kişinin bilirkişi olarak seçimi sağlanabilir. Taşınmaz davaları, iş davaları ve bazı ticaret davaları gibi özel ve teknik bilgi gerektiren davalardan olduklarından, arabuluculuk hizmeti ile dava açılmaksızın çözülme potansiyeli yüksek davalardır. Böylesi bir duruma imkân tanıyan bir use-case tasarımı da use-case'e ayrıca eklenmiştir. 


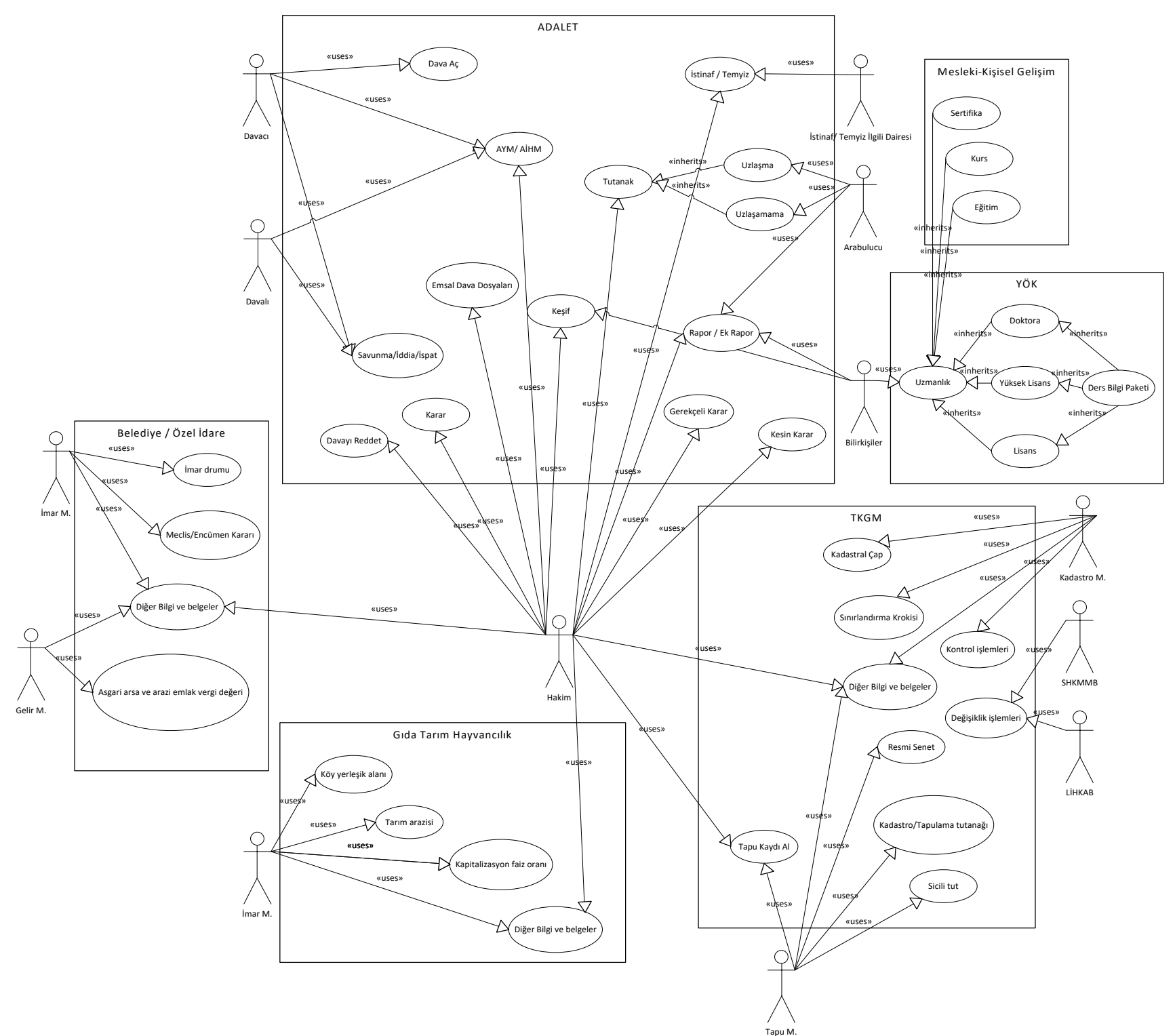

Şekil 4. UML use case (kullanım durum) diyagramı ile gayrimenkul dava sürecinin görselleştirilmesi.

'Gayrimenkul dava sürecinin activity diyagramı ile gösterimi’ Şekil 5’te sunulmuştur. Activity diyagramı ile gayrimenkul davalarının en başından, infazı gerektiren mahkeme kararları için tapuya tescil, infazı gerektirmeyen kararlar için ise kararın kesinleşmesine kadar olan süreç ayrıntıları ile ifade edilmektedir. Activity diyagramı üzerinden süreç ele alındığında, hâkimin hukuk bilgisi ile davanın çözümü mümkün ise davanın daha kısa sürede sonuçlanma ihtimali son derece yüksek görünmektedir. Ancak, gayrimenkul davalarında genel itibariyle çözüm için sıklıkla teknik destek sağlayan bilirkişilere başvurulması, sürecin girift bir yapıya bürünmesine sebebiyet vermektedir. Bilirkişi kurulunun belirlenmesi, keşif, bilirkişi raporunun hazırlanması, raporun mahkemece kabul görüp görmeyeceği, duruma göre ek rapor istenmesi, en nihayetinde yeni bir bilirkişi kurulunun oluşturulmasının talep edilmesi, mahkeme kararı, istinaf değerlendirmesi vb. gibi süreçler, çözümü uzmanlık gerektiren davalarda devreye girmektedir. 


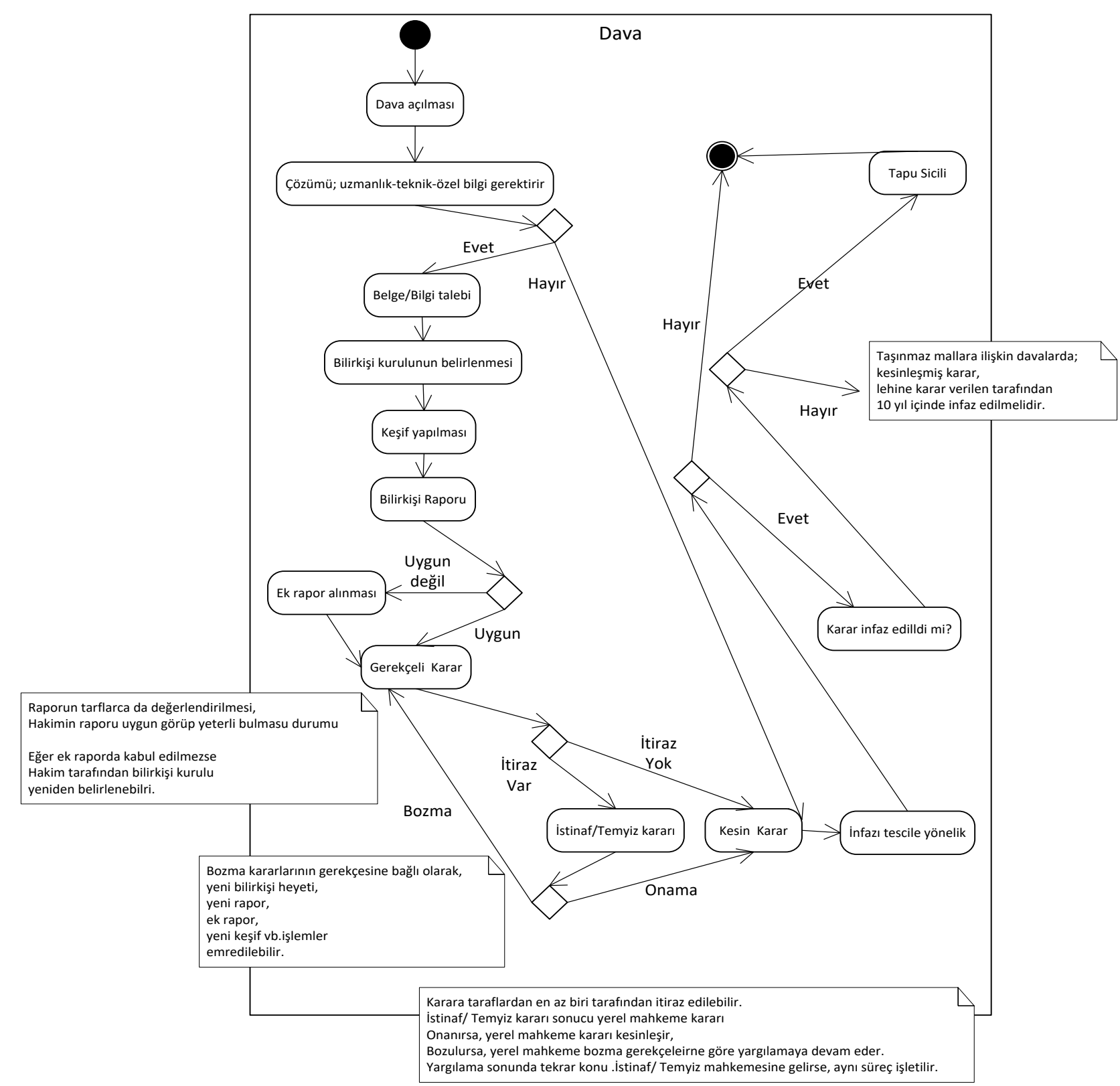

Şekil 5. UML activity (etkinlik) diyagramı ile gayrimenkul dava sürecinin görselleştirilmesi

Şekil 6'da sunulan sequence (sıralama/silsile) diyagramı ile activity diyagramı sayesinde modellenen süreç biraz daha genişletilmiştir. Özellikle mahkemelerin bilgi/belge istemi aşamasında sürece dâhil olacak kurumların öncelikleri belirlenmiştir. Böylece, verilerin temininden sorumlu olduklarını kurumların veri temini esnasındaki öncelik ve sonralık durumları bir arada görülebilir. Bu başlık altında; Tapu Müdürlüğü, Kadastro Müdürlüğü, İmar Müdürlüğü, Gelir Müdürlüğü gibi bütün kurumlar ve kurumlardan talep edilebilecek belgeler belirli bir sıralama çerçevesinde sunulmaktadır. 


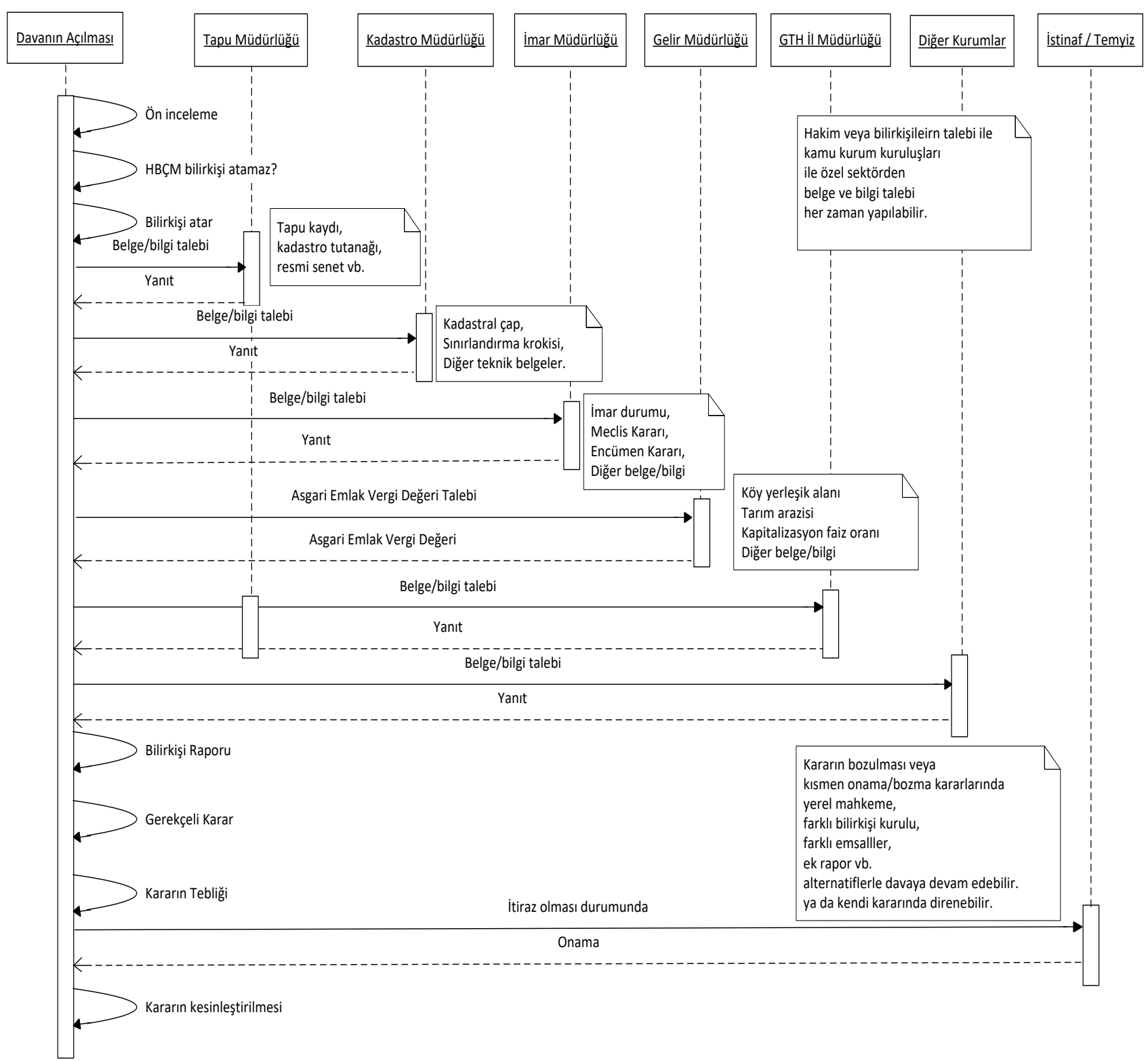

Şekil 6. UML sequence (sıralama-zincir) diyagramı ile gayrimenkul dava sürecinin görselleştirilmesi

UYAP'a uyarlanabilir modelin, e-devletin diğer paydaşları ile ilişkisinin görsel olarak sunulması için UML'nin package (paket) diyagramından yararlanılmıştır (Şekil 7). Gayrimenkul dava sürecinin merkezinde e-devletin adalet kolunu temsil eden UYAP bulunmaktadır. Package diyagramı ile dava süreçlerinin etkin bir biçimde yürütülmesi için UYAP'ın e-devletin hangi paydaşları ile birlikte çalışabilir olması gerektiği modellenmiştir. Kurumlar arası veri alış-verişinin elektronik ortamda yapılması, zaman ve mali tasarruf açısından önem arz etmektedir. 


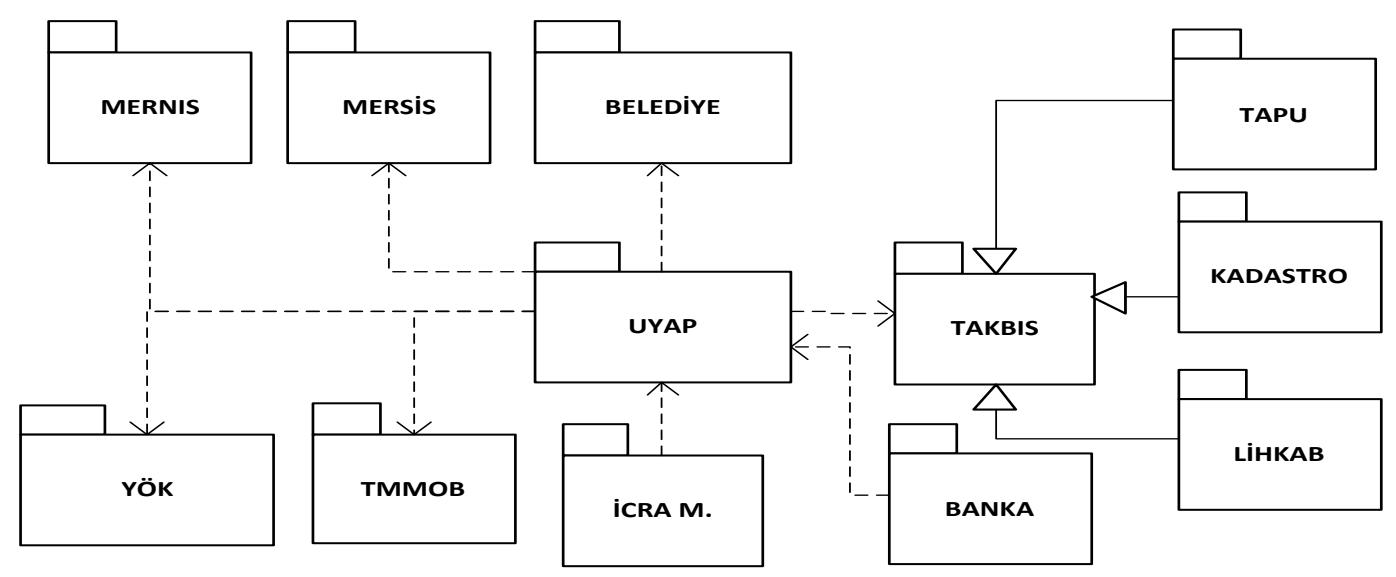

Şekil 7. UML paket diyagramı ile UYAP'ın e-devletin diğer paydaşları ile ilişkisinin görselleştirilmesi

Taşınmaz tabanlı dava sürecine dâhil olan sınıfların birbirleri ile etkileşimlerini ifade eden class diyagramı, Şekil 8'de sunulmuştur. Her bir sınıfın tanımlanması için gerekli nitelikler, o sınıf içerisine yazılmıştır. Örneğin, parsel sınıfını tanımlamak için parselin bulduğu il, ilçe, mahalle, ada ve parsel numarası gibi unsurların bilinmesi gerekmekte olup bu nitelikler parsel sınıfının alt kısmında yerini almıştır. Sistemde tasarlanan sınıflarda; 'TK_' ön eki, parsel, bağımsız bölüm ve konumsal birim içim TKGM tarafından üretilen verilerin tasarlanan sistemle olan ilişkisini göstermektedir. Yani TK_ ön eki TKGM veri tabanına erişerek mevcut sistemler üzerinden, tasarlanan sisteme veri olarak aktarılabilen sınıfları temsil etmektedir. 'MRN_' ön eki, Nüfus ve Vatandaşlık İşleri Genel Müdürlüğü’nün MERNISS projesinden, 'MRS_' ön eki ise Gümrük ve Ticaret Bakanlığ1 Merkezi kayıt Sistemi olan MERSİS’ten elde edilen sınıfları göstermektedir. YÖK Meslek sınıfı ile bilirkişilerin, arabulucuların veya uzmanların alanları ile ilgili sahip oldukları diploma, bu diplomanın eki niteliğinde başardıkları dersler, ders içerikleri, sahip oldukları eğitim sertifikaları vb. bilgiler sorgulanabilecektir. İstinaf/Temyiz sınıfı ise üst mahkemelerin benzer davalarda emsal olarak verdikleri kararlar, yaptıkları incelemelerde eksik görülen hususlar ile cevapları mutlaka olması gereken sorunsalları yansıtmaktadır. 


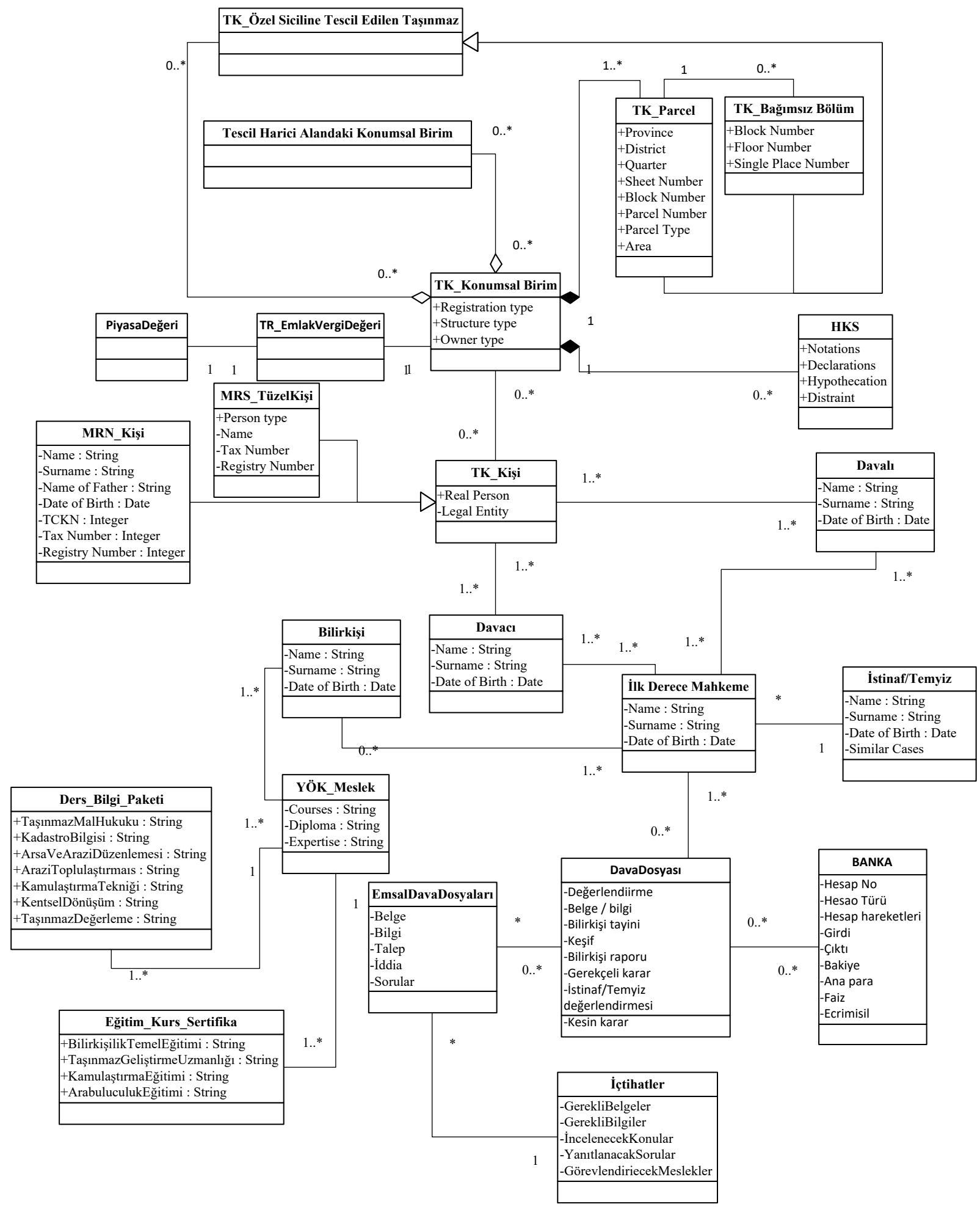

Şekil 8. UML class (sınıf) diyagram ile gayrimenkul dava sürecinin görselleştirilmesi

\section{Sonuç}

Gayrimenkul davaları, adli ilk derece mahkemelerde yüksek paya sahip davalardır. Sulh hukuk mahkemelerine 2017 yılında açılan davaların yaklaşık \%65'i, asliye hukuk mahkemelerine açılan davaların \%25'i ve kadastro mahkemelerine açılan davaların tamamı, konu bakımından doğrudan 
veya dolaylı olarak mülkiyet hakkı ihlali ile ilişkilendirilebilecek türdendir. 2010-2017 y1lları arasında ilk derece adli mahkemelerde davaların ortalama görülme sürelerinin asliye hukukta yaklaşık bir yıl, kadastro mahkemelerinde ise yaklaşık iki yılı bulduğu tespit edilmiştir. Yargıtay'da ise bu süre ortalama altı ayın üzerindedir. Gayrimenkul davaların adli mahkemedeki payı gözetildiğinde bu davaların görülme sürelerinin kısalması, genel ortalama sürelerinin de aşağıya çekilmesine zemin hazırlayabilir.

$\mathrm{Bu}$ çalışmada geliştirilen nesne tabanlı veri modelinin yaygın kullanılan türlerinden olan UML diyagramları üzerinden gayrimenkul dava süreçlerinin nesne yönelimli bir yaklaşımla ele alınması amaçlanmıştır. Bu sayede e-devlet bileşenlerinden UYAP üzerinden davanın açılması ile birlikte, taşınmaz bilgileri TAKBİS'den entegre bir şekilde aktarıldıktan sonra, taşınmazın ve davanın türüne göre bir dizi belge ve bilgi daha davanın açılması ile otomatik olarak toplanmaya başlanacaktır. Tasarlanan modele göre, davanın ve taşınmazın türüne bağlı olarak bilirkişi olarak görev alacak kişiler mesleklerine göre sistem tarafından dinamik olarak belirlenebilecektir. Bu sayede bilirkişi seçimi objektif bir şekilde gerçekleştirilecektir. Dava konusunun çözümü için gerekli belge ve bilgilerin herhangi bir yazışmaya meydan vermeden e-devlet üzerinden sağlanması hızlı ve etkin bir dosya tekâmülü sunacaktır. Bu noktada oluşan zaman kaybı, bilirkişi tayini ve belge-bilgi teminine ilişkin süreçler ortadan kalkacaktır. Sonuç olarak davaların ortalama görülme sürelerinin asgariye çekilmesi adına büyük bir yol alınacağı ifade edilebilir.

Çalışma özelinde taşınmaz mallara ilişkin bazı dava türleri, gerçek uygulamalar üzerinden ele alınarak incelenmiştir. Bu davalar; el atmanın önlenmesi davaları, kadastro davaları, kamulaştırma davaları, kat mülkiyeti davaları ve tapu iptal ve tescil davalarıdır. Bu dava türlerine ilişkin gerçek dava dosyalarına sunulan ve kararlara esas üç-beş kesinleşmiş mahkeme kararı ve ekleri incelenmiştir. Tüm bu taşınmaz davalarında; taşınmazın konumu(mahalle, ada, parsel no vb.), taşınmazın cins ve nevi, taşınmazın yüzölçümü, tapu kayıtları, vergi beyanı, taşınmazın imar durumu, yapılaşma koşulları, kadastro pafta örneği ve kadastro rasat verileri, keşif ölçü krokisi, koordine ve alan özet çizelgesi, uydu veya yer fotoğrafları istisnasız olarak yer etmiştir. Bu verilerin tamamı tapu ve kadastro verileri olarak TUCBS Tapu-Kadastro veri teması ile e-devlet içinde olması hedeflenen verilerdir. Bu tip verilerin çevrimiçi olarak e-devlet araçlarından (UYAP, TAKBİS vb.) elde edilmesi sağlanabilir. Ayrıca emsal taşınmazlarla mukayese, taşınmazın arsa değeri, işgale uğrayan alan hesabı, ecri misil tazminat hesabı, hak tesisi kurulabilecek güzergâhlar, kıyı kenar çizgisi tespiti verileri, amenajman planı, kapitalizasyon faiz oranı, taşınmazın yapı alanı, sınıfı, değeri vb. bilgi ve belgelerde bazı dosyalarda yer bulmuştur. İkinci grupta yer alan bazı veriler arazi çalışması ve bazı verilerse büro çalışmaları ile elde edilebilecek nitelikteki veriler olarak değerlendirilebilir. Özellikle büro çalışması ile elde edilebilecek verilerin e-devlet üzerinde elde edilmesi sağlanabilir. Ancak diğer 
verilerin temini noktasında arazi çalışması yapıp ardından özel ve teknik bilgi ile bu verileri elde etme yoluna gitmek gerekmektedir.

Çözümü uzmanlık gerektiren konularda bilirkişilerin görüşlerine başvurulma yöntemi, yargılamanın doğruluğunu ve seyrini pozitif yönde etkilemektedir. Zira yargıçların kendi uzmanlık alanları dışında konulara hâkim olmaları beklenemez. Geliştirilen anket formunda aktif olarak bilirkişilik yapma potansiyeli olanlar ile bilirkişilik yapanların büyük bir bölümünün akademisyenlerden oluştuğu, bunların çoğunun ise profesör ağırlıklı olduğu göze çarpmaktadır. Çoğunluk ise inşaat ve harita mühendisliği ile İ̈BF ve orman, jeoloji ve jeofizik mühendisliği bölümlerinden mezun ve deneyimli kişilerden oluşmaktadır. Örneklem grubunu oluşturan 78 katılımcının 40 tanesi taşınmaz tabanlı davalarda bilirkişi olarak görev yapmış ve yapmakta olanlardır. Bunların \%70’i, 20 ve üzeri sayıda bilirkişi raporu hazırladığı görülmektedir. Örneklem grubu içinde 100 üzerinde rapor düzenleyen 17 kişinin bulunduğu dikkat çekmektedir.

Meslek disiplinlerinin anket formunda yer alan 41 adet davanın niteliklerine göre hangilerinde görev alabileceklerine ilişkin soruda Harita mühendislerinin arazi nitelikli davalarda \%52, arsa nitelikli olanlarda ise \%51 ile ilk sırayı aldığı görülürken bina nitelikli davalarda ise \%41 ile İnşaat mühendisleri ön plana çıkmaktadır. Bu durum ankete katılımda İnşaat ve Harita mühendislerinin yüksek paya sahip olması ile izah edilebileceği gibi anket formunda yer alan dava konularının bu meslek disiplinlerinin uzmanlık alanlarına daha fazla girdiği sonucuna da varılabilir. Buna rağmen meslek disiplininin lisans müfredatında hiçbir ders olmamasına rağmen bazı dava türlerinde çok yüksek oranda bilirkişilik yapabileceği sonucu dikkat çekmektedir. Temel olarak arsa nitelikli taşınmazlarda harita mühendisi, arazi vasıflı taşınmazlarda ziraat mühendisliği, yapılı taşınmazlarda ise inşaat mühendisliği disiplini ilgili bilirkişi olarak değerlendirilmiştir. Buna rağmen, arsa ve arazi ayrımı, arsa veya arazi üzerinde ağaç ve yapı gibi muhdesatların bulunması, arazi üzerinde farklı ürünlerin hasat miktarlarından gelir yöntemi ile değerleme yapılması vb. gerekliliği göz önüne alınmalıdır. Yine de bu konuda, çalışma özelinde ele alınan anket sorularının geliştirilerek uygulanmasının son derece faydalı olacağı ifade edilmelidir. Örneklem grubu olarak sadece meslek disiplini mensuplarının tek başına verdiği yanıtlar üzerinden gitmek doğru bir yaklaşım olmayabilir. $\mathrm{Bu}$ nedenle davaları karara bağlayan hâkimlerden oluşan bir kontrol grubunun da farklı bir örneklem olarak ele alınması son derece yararlı olacaktır. Son olarak gerek bilirkişilik yapacak meslek mensuplarının öğrenim gördükleri alanlardaki akademisyenler ile hâkimlerin öğrenim gördükleri hukuk fakültesi akademisyenleri de diğer bir örneklem kontrol grubu olarak ele alınmalıdır. Özetle sürecin her aşamasında yer alan herkesin tecrübe ve fikirlerinin yansıtıldığı arama konferansları ve çalıştaylardan çıkacak sonuçların ele alınması şiddetle önerilmektedir.

Çalışmanın son aşamasını gayrimenkul dava süreçlerinin nesne tabanlı veri modelinin yaygın unsurlarından UML diyagramları ile görselleştirilmiştir. Geliştirilen veri modeli ile sürece dâhil olan 
gerçek/tüzel kişilerin görev, yetki ve sorumluluklarının sunulması, dava sürelerinin istenen seviyeye çekilmesi ve mülkiyet hakkının önemli bir parçası olan gayrimenkul dava süreçlerinin üçüncü kişiler tarafından rahat bir şekilde kavranması amaçlanmıştır.

UML iş akış diyagramı ve activity diyagramları ile dava süreci net bir biçimde ortaya konulmuş, çalışmanın temelini oluşturan bilirkişilik kurumunun davalara dâhil olma şartları, yapılması gerekenler belirtilmiştir. UML use case diyagramları, taşınmaz tabanlı davalarda yer alabilecek aktörlerin kimler olacağını, ihtiyaç duyulan verilerin hangi kurumdan ne şekilde temin edileceğini göstermiş, bir nevi süreç içerisine dâhil olan aktörlerin görev tanımlarına ilişkin bilgiler sunmuştur. UML sequence diyagramları üzerinden ihtiyaç duyulan verilerin temininde kurumların öncelik/sonralık durumları belirlenmiştir. UML package diyagramı, e-devlet üzerinden veri elde etmeye imkân sunan kurumlar ile e-devletin yargı ayağını teşkil eden UYAP arasındaki ilişkiyi ortaya koyarken, class diyagramı ile sürece dâhil olan her bir sınıfın tanımlanması için gerekli niteliklere erişimi mümkün hale getirmiştir.

Tasarlanan nesne tabanlı model ile dava sürelerinden bazı iyileştirmeler yapmak mümkün olacaktır. Ancak daha etkili bir sonuç almak için bilirkişilere ilişkin daha etkin ölçütlerin olduğu bir yazılım üzerinden kontrol ve güncellemelerin yapılması gerekmektedir. Bu çalışmada yapılan anket yöntemine benzer bir sistem ile meslek disiplinlerinin hangi davalarda bilirkişi olarak görev alabileceklerinin bir standarda kavuşturulması gerekmektedir. Bunun için mezun olunan bölümde alınan dersler, sahip olunan sertifika belgeler, dava deneyimi, dava kapsamında hazırlanan bilirkişi raporlarının mahkeme tarafından kabul görme oranı gibi kriterler, otomasyon üzerinden yürütülmeli, davanın maddi/manevi önem derecesine göre bu kriterlerden bazıları veya tamamı devreye sokulmalıdır. Bunun yanında bilirkişiler, görev aldıkları davalar için raporunda bulundurması gereken bilgi/belgeleri sistem üzerinden anında görüp verilerin temin edileceği kurumlar ile aynı sistem üzerinden iletişim kurabilmelidir. Nihayetinde mahkeme başkanının birkaç tuş ile bilirkişi atayabildiği, taşınmaz ve davanın türüne göre bu bilirkişilerin yanıtlayacağı soruların yöneltildiği, hem hâkimin hem de bilirkişilerin ihtiyaç duyulan verilere ulaşabildiği bir sistem inşa edilmelidir. Böylece makul sürelerde tamamlanan davalar ile yargı sistemi daha hızlı ve daha hassas kararla ile daha da güçlendirilebilir.

Son olarak iş ve bazı ticaret davaları için ön şart olan uzlaştırmacı ile görüşme gibi bir şartın gayrimenkul davaları için uygulamaya alınabileceği değerlendirilmelidir. Zira çoğu zaman çözümü özel ve teknik bilgi gerektiren bu tip davalar, bu özel ve teknik bilgi sahipleri ile mahkeme öncesi iddia ve savunmalarını yetkili makamlar önünde şeffaf bir şekilde tartışabilir. Bu sayede mahkeme aşamasında toplanan veriler önceden sağlanabilir, yine uzlaştırmacı tarafından raporlar hazırlanıp bu raporlar üzerinden olayın tüm tarafları bir araya getirilebilir. Bu aşamada anlaşma durumunun çok büyük sıklıkla görüleceği düşünülmektedir. Zira ne şikâyetçi ne de şikâyet edilen taraf olay öncesi, 
olaya konu tüm belge ve bilgileri yargı sistemi içinde açık ve şeffaf bir biçimde elde etme ve uzmanına yorumlatma şansına çoğu zaman sahip olamamaktadır. Uzman tarafından yapılan bu değerlendirme adalet sistemi içinde olacağından olayı tüm açıklığı ile birlikte ortaya koyacaktır. Bu noktada çoğu kez anlaşma imkânı bulunacağı ve sorunun çözüleceği ihtimali göz önüne alınmalıdır. Çözüm olmadığı takdirde konu tekâmül etmiş dosya ile birlikte yargıç önüne mutlaka gelecektir.

\section{Yazarların Katkısı}

Tüm yazarlar çalışmaya eşit katkıda bulunmuştur.

\section{Çıkar Çatışması Beyanı}

Yazarlar arasında herhangi bir çıkar çatışması bulunmamaktadır.

\section{Araştırma ve Yayın Etiği Beyanı}

Yapılan çalışmada araştırma ve yayın etiğine uyulmuştur.

\section{Kaynaklar}

Akil, C. (2011). Medeni yargılama hukukunda mahkeme tarafından atanan bilirkişi-uzman tanık ayrımı. Ankara Barosu Dergisi(2), 171-183.

Avaner, T., \& Fedai, R. (2019). Türk Kamu Yönetiminde Ofis Sistemi: E-Devlet Uygulamalarından Dijital Dönüşüm Ofisine. Amme Idaresi Dergisi, 52(2).

Avrupa İnsan Hakları Sözleşmesi. (1950). İnsan Haklarının ve Temel Özgürlüklerinin Korunmasına İlişkin Sözleşme. Roma, 4, 1950.

Aymaz, A. (2017). 6100 sayılı Hukuk Muhakemeleri Kanunu'na göre Sulh Hukuk Mahkemelerinin kira ilişkisinden doğan davalarda görevi According to the civil procedure law numbered 6100, duties of the civil courts of peace for the tenancy relationship conflict cases.

Batır, U. (2013). E-Devlet Uygulamalarından Adalet Bakanlığı Ulusal Yargı Ağı Bilişim Sistemi Portalı (UYAP)'ın Etkinliğini Belirlemeye Yönelik Ankara Barosu Avukatları Üzerine Bir Alan Araştırması. In: Yayınlanmış Yüksek Lisans Tezi. Ankara: Gazi Üniversitesi. Eğitim Bilimleri ....

Benli, H. E. (2015). Yargı Sisteminin Etkin İşleyişi ve Ekonomik Büyüme: Türkiye Örneği, 1980-2010. (Doktora Tezi). Atılım Üniversitesi, Sosyal Bilimler Enstitüsü, Ankara.

Bruce, J. (1998). Tenure Brief, Review of Tenure Terminology, Land Tenure Center. An Institute for Research and Education on Social Structure, Rural Institutions, Resource Use, and Development, University of Wisconsin, 8.

Çepni, S. (2010). Araştırma ve proje çalışmalarına giriş.

Cohen, L., Manion, L., \& Morrison, K. (2013). Research methods in education: routledge.

Çoruhlu Y. E., ve Demir, O., (2014). Vakıf Taşınmazların Yönetim Sorunlarının Tespit Edilmesine Yönelik Bir Durum Tespiti Çalışması. Gümüşhane Üniversitesi Fen Bilimleri Dergisi , vol.4, no.1, 94-106.

Çoruhlu, Y. E., Uzun, B., \& Yildiz, O. (2020). Zoning plan-based legal confiscation without expropriation in Turkey in light of ECHR decisions. Land use policy, 95, 104598. 
Çoruhlu, Y. E., Demir, O., Yıldız, O., \& Yılmaz, H. (2016). Kültür Varlığı Tescilli Taşınmazların, Kurucu Vakıfları Adına Tescili: Vakıflar Kanunu 30. Madde Uygulaması. İstanbul Barosu Dergisi. C, 90, 1.

Dale, P., \& McLaughlin, J. (1999). Land Administration. In: Oxford University Press Inc.

Denscombe, M. (2014). The good research guide: for small-scale social research projects: McGraw-Hill Education (UK).

Durman, O. (2002). Yargıtay Kararları Işı̆̆ında Kadastro Mahkemelerinde Yargılama. Beta Yayınları.

Ercan, İ. (2000). Yargıtay Kararlarında Oluşan Son Eğilimlerle Kamulaştırma, Acele İşlerde El Koyma, Acele Kamulaştırma. İstanbul, yy.

Eren, F. (1977). The meaning to be given to the concept of property of civil law according to the constitution and new developments. $A \ddot{U} H F$ Yayınları, 408.

Eren, F. (2012). Property Law: Yetkin Publising.

Gazete, R. (20.01.1982). İdari Yargilama Usulü Kanunu. Erişim adresi: http://www. mevzuat. gov. tr/MevzuatMetin/1.5, 2575.

Gençay, G. (2016). Orman sınırları içinde tapu iptali kararlarının mülkiyet hakkını ihlal etmesi sorunu. İstanbul Üniversitesi Orman Fakültesi Dergisi, 66(1), 75-89.

Göktepe, H. (2010). Türk Hukukunda Kamulaştırma-Kamulaştırmasız El Atma ve Eşya Hukuku Yönünden Sorunlart. Yüksek Lisans Tezi, ÏÜ Sosyal Bilimler Enstitüsü, İstanbul,

Göktepe, H. S. (2010). Türk Hukukunda Kamulaştırma-Kamulaştırmasız El Atma ve Eşya Hukuku Yönünden Sorunları. Yüksek Lisans Tezi, ÏÜ Sosyal Bilimler Enstitüsü, İstanbul,

Görgülü, H. H. (2005). Veri Zarflama Analizi ve Türk Yargı Sisteminin Etkinliğinin İncelenmesi. (Yüksek Lisans Tezi). Muğla Üniversitesi, Fen Bilimleri Enstitüsü, Muğla.

Güler, A., \& Karaca, C. (2017). Bilirkişilik Müessesesi ve Vergilendirilmesi 2nd International Conference on Scientific Cooperation for the Future in the Economics and Administrative Sciences, 159-164.

Güreler, S.. (2011). Kamuda etkinlik, verimlilik ve e-devlet. DEÜ Sosyal Bilimleri Enstitüsü,

Güzel, D., \& Deligöz, K. (2014). Uyap Bilişim Sisteminin Türk Yargı Sisteminde Kullanılmasının Toplam Kalite Yönetimi Açısından İncelenmesi. Bingöl Üniversitesi Sosyal Bilimler Enstitüsü Dergisi, 4(7), 63 78.

Kök, A. N. (2017). 6754 sayılı bilirkişilik kanunu neler getirdi? Journal of Judgments by the Court of Jurisdictional Disputes/Uyusmazlik Mahkemesi Dergisi(10).

Kuru, B., Arslan, R., \& Y1lmaz, E. (2013). Medeni Usul Hukuku Ders Kitab1, 24. B, Ankara: Yetkin.

Küçükyağcı, N. (2012). Geçmişten Günümüze Türk Yargı Sistemi Ve Yargı Bürokrasisi. (Başbakanlık Uzmanlık Tezi). Ankara.

Meriç, A., Erkuş, H., \& Kaygusuzoğlu, M. (2016). Bilirkişilik Müessesesinde Yaşanan Sorunlarla İlgili Muhasebe Meslek Mensupları Ve Hakimlerin Algısı Üzerine Bir Araştırma. Journal of Accounting \& Finance(71), 23,24.

Odabaş, H. (2008). Elektronik Belge Düzenleme Yaklaşımları ve Türkiye'de E-devlet Uygulamalarında Elektronik Belge Yönetimi-Electronic Records Arrangement Approaches and Electronic Records Management at E-government Applications in Turkey. Atatürk Üniversitesi Sosyal Bilimler Enstitüsü Dergisi, 12(2), 121-142.

Özdemir, Y. (2018). Türk Hukukunda kamulaştırmasız el atma/Confiscation without expropriationin Turkish Law.

Özmen, E. S., \& Aydın, G. S. (2014). Tapu İptal Davası Olarak Yanlış Adlandırma ile Açılan Davalar (Tescili İsteme Davas1/Yolsuz Tescilin Düzeltilmesi Davas1). İstanbul Barosu Dergisi, C, 88, 6.

Papakçı, A. (2016). Hukuki Bilirkişilik. Marmara Üniversitesi Hukuk Fakültesi Hukuk Araştırmaları Dergisi, $22(1), 433-456$.

Pehlivan, C. (2008). Kamulaştırmada bedel tespiti. İstanbul Kültür Üniversitesi/Sosyal Bilimler Enstitüsü/Hukuk Anabilim Dalı,

Pekcanıtez, H., Atalay, O., Özekes, M., Atalı, M., Erdönmez, G., Akkan, M., . . Taş Korkmaz, H. (2013). Medenî Usûl Hukuku, 14. Bası, Ankara.

Resmi Gazete. (2.7.1965). Kat Mülkiyeti Kanunu. (12038).

Resmi Gazete. (4.2.2011). Türk Borçlar Kanunu. (27836).

Resmi Gazete. (7.10.2004). Adlî Yargı İlk Derece Mahkemeleri ile Bölge Adliye Mahkemelerinin Kuruluş, Görev ve Yetkileri Hakkında Kanun. (25606).

Resmi Gazete. (8.9.1956). Orman Капипu. (9402).

Resmi Gazete. (8.11.1983). Kamulaştırma Kanunu. (18215).

Resmi Gazete. (8.12.2001). Türk Medeni Kanunu. (24607).

Resmi Gazete. (9.7.1987). Kadastro Kanипu. (19512). 
Resmi Gazete. (26.1.2013). Yargıtay Büyük Genel Kurul Kararı. (28540).

Resmi Gazete. (1982a). Kanunu, İdari Yargılama Usulü, Resmi Gazete (Sayı: 17580). Erişim adresi: http://www. mevzuat. gov. tr/MevzuatMetin/1.5, 2575.

Resmi Gazete. (1982b). Türkiye Cumhuriyeti Anayasası. Başbakanlık Basımevi, 17863, 129-182.

Sezer, Ö., \& Cengiz, S. (2019). Yeni Kamu Yönetimi Anlayışının Türk Yargı Sistemine Etkileri. Mehmet Akif Ersoy Üniversitesi Sosyal Bilimler Enstitüsü Dergisi, 9(20), 196-215.

Şahiniz, S. (2006). Teoride ve uygulamada kamulaştırmasız el koyma. Seçkin Yayıncılık, Ankara.

Şimşek, S. (2014). Arazi ve Arsa Düzenlemesi İşlemlerinin İptaline İlişkin Yargı Kararının Sonuçları ve Eski Halin İhyası İçin Açılacak Davalarda Görevli Yargı Meselesi. Adalet Dergisi(48 s 291), 308.

Taş, İ. E., Uçacak, K., \& Çiçek, Y. (2017). Türk Kamu Yönetiminde Yaşanan Dijital Dönüşümün Bürokratik İşlemlerin Azaltılması üzerindeki Etkileri. Türk Kamu Yönetiminde Yaşanan Dijital Dönüşümün Bürokratik İslemlerin Azaltılması Üzerindeki Etkileri, 22.

Türk, D. (2005). İnşaat Sözleşmelerinde Uyuşmazlıklar ve Uyuşmazlıkların Çözüm Yolları. Fen Bilimleri Enstitüsü,

Türkan, A., \& Erdinçertürk, A. (2017). Akademik Çalışmalar Bağlamında UYAP'a Bakış. Dicle Üniversitesi Adalet Meslek Yüksekokulu Dicle Adalet Dergisi, 1(2), 69-86.

"Http://Www.Adlisicil.Adalet.Gov.Tr/Istatistik_2017/Istatistik2017.Pdf." 2017, accessed 10/09/2018.

"Dava Türleri." Erişim adresi: https://vatandas.uyap.gov.tr/main/vatandas/index.jsp?v=1288, 2020, accessed 3.24.2020, 2020.

Wellington, J. (2015). Educational research: Contemporary issues and practical approaches: Bloomsbury Publishing.

Yeşil, U. (2015). Uyuşmazlık Mahkemesi Ve Türk Yargı Sisteminde Görev ve Hüküm Uyuşmazlıklarının Çözüm Usulü. (Doktora Tezi). Kırıkkale Üniversitesi, Sosyal Bilimler Enstitüsü, Kırıkkale.

Yıldırım, R., Odyakmaz, Z., Atik, A. Ç., Çalışkan, A. Z., Ersöz, A. K., \& Deniz, Y. (2016). İdare Mahkemeleri Örneğinde Bilirkişilik Uygulamaları. Selçuk Üniversitesi Hukuk Fakültesi Dergisi, 19(1), 9-38. 